Uluslararası Sosyal Bilgilerde Yeni Yaklaşımlar Dergisi,2020, 4(1), 17-44

International Journal of New Approaches in Social Studies, 2020, 4(1), 17-44

\title{
Türkiye ve Azerbaycan'da Ortaokul 7. Sınıf Düzeylerinde Coğrafya Konularının Karşılaştırılması ${ }^{*}$
}

\author{
Selçuk ILGAZ ${ }^{1 * *} \&$ Murat ÇAYKESEN ${ }^{2}$
}

Gönderilme Tarihi:22 Kasım 2019

Kabul Tarihi: 04 Mart 2020

DOI: $10.38015 /$ sbyy. 649950

\begin{abstract}
$\ddot{O} z:$
Bu araştırma Türkiye'de ortaokul 7. sinif düzeyinde okutulan sosyal bilgiler dersi coğrafya konuları ile Azerbaycan'da aynı sinıf düzeyinde okutulan coğrafya dersinin, ögretim programları ve ders kitapları esas alınarak tarama modeli ile karşılaş̧tırllip benzer ve farkl yönlerinin ortaya konulması amactyla yapılmıştır. Araştırmada nitel araştırma yöntemleri kullanilarak doküman analizi tekniği uygulanmiştır. Veriler bu tekniğe uygun olarak toplanmuştır. Veri toplamaya konu ile ilgili daha önce yapılmış ilgili araştırmalar incelenerek başlanmış olup, daha sonra her iki ülkede araştırmaya konu olan düzeyde ilgili derslere ait okutulmakta olan ders kitaplar temin edilmiştir. Genelden özele anlayışı ile incelemeye; ülke özellikleri, eğitim sistemleri, ortaokul coğrafya müfredatları ve ders kitapları incelenerek karşılaş̧tırma yapılmuştır. Bu çalı̧̧ma sonucunda; her iki ülkenin genel özelliklerinin, Türk dili temelinde incelenmesiyle kültürel olarak benzer özellikler taşıllğ görülmüş̧ür. Eğitim sistemlerinde genel amaçlar, zorunlu eğitim ve eğitim sistemlerinin genel yapısının ana hatlarıyla benzer özellikler taşılığı görülmüştür. Araştırmaya konu olan 7. sinıf düzeyinde Türkiye'de, tarih, coğrafya ve vatandaşlık konularinın içinde yer aldiğ sosyal bilgiler isimli ders okutulurken, Azerbaycan'da Türkiye'den farkl olarak coğrafya ve tarih dersleri birbirinden bağımsız olarak iki ayrı ders olarak okutulduğu tespit edilmiştir. Her iki ülkenin eğitim sistemleri Türkçe temelinde genel olarak benzer özellikler taşıldı̆̆ tespit edilmiştir. Öğretim programı yapısında Türkiye'de sosyal bilgiler içerisinde coğrafya programina daha fazla yer verilmesi dersi daha somutlaştıracaktır. Ders kitapları olarak Azerbaycan'da okutulan ders kitabının baskı kalitesinin ve görselliğinin artırlması olumlu olacaktır.
\end{abstract}

Anahtar Kelimeler: Sosyal bilgiler, karşılaş̧tırmalı eğitim, Azerbaycan eğitim sistemi, cografya.

\begin{abstract}
:
The aim of this research is revealing the similarities and differences between geography lessons in Social Studies at the 7th grade level in the middle school in Turkey and Geography in Azarbaijan with comparing with curricula and textbooks based on the model. Document analysis technique was applied in the research using qualitative research methods. The data was collected according to this technique. The data collection was started by examining the related researches that was related to the topic and then, the textbooks were provided in both countries. Country characteristics, education system, secondary school Geography curricula and textbooks were examined
\end{abstract}

\footnotetext{
${ }^{1}$ Atatürk Üniversitesi, Türkiye. Orcid ID: 0000-0003-0441-5230

${ }^{2}$ Milli Eğitim Bakanlığı, Türkiye. Orcid ID: 0000-0003-3475-5535

* Murat Çaykesen tarafından Atatürk Üniversitesi Sosyal Bilimler Enstitüsünde yapılan "Türkiye ve Azerbaycan'da Ortaokul

7. Sınıf Düzeylerinde Coğrafya Müfredatlarının Karşılaştırılması" isimli yüksek lisans tezinden türetilmiştir.

**Sorumlu Yazar (Corresponding Author): ilgaz@atauni.edu.tr
} 
from the general to the specific. As a result of this study, it has been observed that the general characteristics of both countries have similar cultural characteristics when examined on the basis of Turkish language. It has been seen that educational systems have similarities with the general outlines of the general purpose of education systems. In Turkey, History, Geography and Citizenship subjects are in the same class but in Azerbaijan Geography and History are seperated from each other. It has been determined that education systems of both countries have similar characteristic on the basis of Turkish language. Giving more place to the Geography in Social Studies will embody the lesson in Turkey.It will be better to increase the print quaility and visual quality of coursebook which is taught in Azarbaijan as a textbook.

Keywords: Social studies, comparative education, Azarbaijan education system, geography.

\section{GíRiş}

Eğitim bireylerde "davranış değiştirme" süreci olarak tanımlanmaktadır. Süreç sonucunda eğitilen bireylerin davranışları da değişebilmektedir. Bu değişim; bireyi çevreleyen toplumsal ve ekonomik koşullara, içinde yaşanan kültüre, değer yargılarına ve eğitim biliminin gelişmişliğine bağlıdır (Türkoğlu, 2012). Eğitim süreci, bireylerin güncel ve doğru bilimsel bilgiye ulaşmasıyla başlar. Sonucunda da doğru bilgilerle donatılmış çağdaş bireylerin toplumda yer edinmesiyle; toplumsal olarak gelişim sağlanır. Bunun için ülkeler, vatandaşlarının eğitimine çok önem vermek, eğitim konusuna hassasiyetle eğilmek ve eğitim sistemlerini sürekli güncelleyerek çağdaş seviyeye yükseltmek zorundadır (Kab, 2012).

Eğitim ve öğretimin bir toplumun gelişmesinde, kalkınmasında ve bununla birlikte her alanda hayati bir önem taşıdığı bilinmektedir. Sosyal bilgiler eğitimi de bireyin toplumsal, ekonomik ve kültürel alanda yaşanmakta olan değişim ve gelişimi kavramasını amaçlamıştır. Sosyal bilgilerin bir eğitim programı olarak ilk uygulandığı yer olan Amerika Birleşik Devletleri'nde 19. yüzyıl Amerikan yöneticileri, kültürleri kaynaştırmak, bir arada yaşama bilincini oluşturmak, kolektif çalışma ve ortak karar alma mekanizmalarını işletmek, kısacası "yeni Amerikan toplumu yaratmak” için eğitimi araç olarak görmüşlerdir. Böylece 1892'de Ulusal Eğitim Konseyi toplanıp Anglosakson kültür temelli milli toplum anlayışı oluşturmak üzere, sosyal bilim disiplinlerinden oluşan, sosyal bilgiler dersi öğretim programı hazırlamıştır (Bilgili, 2012; Öztürk, 2012; Tay, 2011). Safran (2008, s. 14), Türkiye'de sosyal bilgiler isminin ne zaman ve ne şekilde ortaya çıktığını şu cümlelerle belirtmektedir: "Ülkemizde sosyal bilgiler ismi, 1968-1969 öğretim y1lında bütün ilkokullara, 1970-1971 öğretim y1lında da deneme niteliğinde ortaokullara resmen girmiştir. Daha sonra Millî Eğitim Bakanlığı Talim Terbiye Kurulu Başkanlığının 9. Millî Eğitim Şûrası kararları uyarınca, 15.11.1974 tarih ve 459 sayılı kurul kararı ile temel eğitim 4., 5., 6., 7. ve 8. sinıflarda sosyal bilgiler dersinin okutulmasına karar verilmiştir." Türkiye'de sosyal bilgiler öğretim programları birçok değişikliğe uğramış ancak daima çağdaş eğitim hareketlerine paralel olarak yapılandırılmıştır (Öztürk, 2012). 1980 darbesi sonrası, sosyal bilgiler dersinde yine değişiklikler yapılmış ve 1985 yılında sosyal bilgiler dersi yerine Milli Coğrafya ve Milli Tarih dersleri konulmuştur (Bilgili, 2008; Uslu, 2014). 1998 yılında tekrar sosyal bilgiler adını alan ders, Millî Eğitim Bakanlığı'nın 2004 yılındaki tüm ilköğretim programlarındaki değişikliği ile yeniden oluşturulmuştur.

Azerbaycan'da ise sosyal bilgiler adı altında bir ders bulunmamaktadır. Sosyal bilgilere karşılık gelecek şekilde coğrafya, tarih ve vatandaşlık dersleri ayrı ayrı dersler olarak okutulmaktadır. Azerbaycan Cumhuriyeti Bakanlar Kurulunun 2006 yılında onayladığ 1 "Milli Program" devlet için çok önemli bir belge olarak kabul edilmiştir. Eğitim programları bu belgeye göre hazırlanmaya başlanmış ve devam ettirilmiştir. Ayrıca 2013 yılında Azerbaycan Cumhuriyeti Eğitim Bakanlığı tarafından hazırlanan "Azerbaycan Cumhuriyeti'nin eğitim alanında Reform 
Programı", Azerbaycan'da eğitim reformlarının hayata geçirilmesi için ilk ivme olmuştur (Azerbaycan Cumhuriyeti Eğitim Bakanlığı, 2013). Azerbaycan eğitim sisteminde coğrafya dersi ortaokullarda; 6, 7, 8, 9 ve 10. sinıflarda haftada 2'şer saat okutulmaktadır. Bu çalışmada ise Türkiye'de ilköğretim 7. sınıfta okutulan sosyal bilgiler dersi içerisinde yer alan coğrafya konuları ve Azerbaycan'da 7. sınıfta okutulan coğrafya dersinin içerikleri karşılaştırılacaktır.

Farklılıkların ortak bir paydada birleştirilmesinin çok önemli olduğunu ortaya koymak için gerekli yöntem olan karşılaştırmalı eğitimin, farklı ülkelerin eğitim sistemlerinin incelenmesi sonucunda benzer ve farklı yönlerin ortaya çıkarılarak ortak sorunlara çözüm üretmek için yapılan araştırmaları içeren bir çalışma alanı olduğu söylenebilir (Adıgüzel ve Tatlı, 2012). Günümüzde ülkeler eğitim ile ilgili reformlar yaparken, eğitim sorunlarını tartışırken karşılaştırmalı eğitime ihtiyaç duymaktadırlar (Ergün,1985). Karşılaştırmalı eğitimin farklı ülkelerde, birden fazla eğitim sisteminin benzer ve farklı yönlerini tespit edip, benzer özelliklerini ortaya koyarak insanlara farklı eğitim sistemleri konusunda yararlı teklifler sunan bir çalışma alanı olduğu söylenebilir (Türkoğlu, 2012). Karşılaştırmalı eğitimin farklı ülkelerde uygulanan eğitim sistemlerinin benzer ve farklı yönlerini açıklamaya çalışan, benzer yönleri ortaya çıkararak insanlara eğitim sistemleri konusunda yararlı teklifler getiren bir alan olmasının yanı sıra; farklı eğitim politikaları ve uygulamalarını da inceleme olanağı verdiği görülmektedir (Kızıltaş ve Küçükoğlu, 2012). Erdoğan (2006)'a göre karşılaştırmalı eğitim sayesinde; eğitim sorunlarında farklı ülkelerin nasıl çözüm ürettiği öğrenilebilir. Karşılaştırmalı eğitim, ortaya çıkardığı değişik deneyim ve yaklaşımlarla eğitim alanında en doğru kararı vermeye yardımcı olur. Bu sayede sunulan farklı örneklerle eğitim ile ulusal kalkınma arasındaki ilişkinin değişik boyutları görülebilir. Ayrıca eğitim politikalarının belirlenmesi ile geçmişten ders çıkarıp geleceğe yatırım yapılır ve başka ülkelerin eğitim sistemi ile ilgili sunduğu güvenilir bilgilerle ülkedeki eğitim sorunların çok özel olmadığını gösterir. Başka bir ülkede yapılan araştırma sayesinde kendi ülkemizde yeni teoriler üretmemizi sağlar. Eğitim bilimleri çalışmaları karşılaştırma sayesinde daha etkili bir zemine oturur.

$\mathrm{Bu}$ çalışmada da yukarıda belirtilen nedenlerden dolayı Türkiye ve Azerbaycan eğitim sistemlerinin karşılaştırılması amaçlanmıştır. Çalışmanın problem cümlesini "Türkiye ve Azerbaycan'ın eğitim sistemleri ile Türkiye 7. sınıf sosyal bilgiler dersi coğrafya konuları ve Azerbaycan 7. sınıf coğrafya dersi konularının içerik ve ders kitabı açısından benzer ve farklı yönleri var mıdır?" cümlesi oluşturmuştur. Bu problem cümlesine bağlı olarak da üç alt problem üzerinde durulmuştur. Alt problemler aşağıdaki gibi şekillenmiştir;

1. Türkiye Cumhuriyeti ve Azerbaycan Cumhuriyeti'nin eğitim sistemlerinin temel özellikleri nelerdir?

2. Türkiye'de 7. sınıf sosyal bilgiler dersi coğrafya konuları ile Azerbaycan'da 7.sınıfta okutulan coğrafya konularının, öğrenme alanları ve üniteler açısından benzer ve farklı yönleri nelerdir?

3. Türkiye'de 7. sınıf sosyal bilgiler ders kitabı ile Azerbaycan'da 7.sinıfta okutulan coğrafya ders kitabının görsel açıdan benzer ve farklı olan özellikleri nelerdir?

\section{Araştırmanın Amact}

Bu araştırmada, Türkiye' de ilköğretim 7. sınıfta okutulan sosyal bilgiler dersi coğrafya konuları ile Azerbaycan'da aynı yaş grubuna okutulan 7. sınıf coğrafya konularının muhtevası ve ders kitaplarının şekil yönüyle benzerlik ve farklılıklarının ortaya çıkarılarak karşılaştırılması amaçlanmıştır. Birden fazla ülkenin eğitim sistemlerini karşılaştırırken tek amaç benzer ve farklı yönleri tespit etmek değildir. Asıl amaç karşılaştırılan ülkelerin eğitim sistemlerinden 
elde edilen bilgilerden olumlu yönde faydalanmaktır (Güven ve Gürdal, 2011). Karşılaştırma ile eksiğimizi, fazlamızı, iyi ve kötü yönlerimizi, karşılaştırılan ülke/ülkelerin iyi ve kötü yönlerini görebiliriz. Dolayısı ile mukayese etmeden ne kendimizi ne de bir başkasını anlayabiliriz (Atik, 2014).

\section{YÖNTEM}

"Nitel araştırma gözlem, görüşme ve doküman analizi gibi nitel veri toplama yöntemlerinin kullanıldığı, algıların ve olayların doğal ortamda gerçekçi ve bütüncül bir biçimde ortaya konmasına yönelik nitel bir sürecin izlendiği araştırma olarak tanımlanabilir" (Yıldırım ve Şimşek, 2011, s. 39). Doküman analizi elde edilen dokümanların ayrıntılı bir şekilde incelenmesiyle gerçekleştirilir. Nitel araştırmacılar için en önemli bilgi kaynağı dokümanlardır. Araştırmacılar ilgilendikleri konuya ilişkin gereken bilgileri zamandan ve paradan tasarruf ederek doküman incelemesi yöntemiyle daha kolay elde edebilir (Yıldırım ve Şimşek, 2011). Nitel araştırma yöntemleriyle gerçekleştirilen bu çalışmada Creswell (2013)'e göre belirli bir zaman diliminde bir veya birden fazla durumun gözlem, görüşme, doküman ve rapor gibi araçlar kullanılarak derinlemesine incelendiği bir nitel araştırma yöntemi olan durum çalışması modelinin, her bir durumun tek başına bütüncül olarak ele alınıp daha sonrada birbirleriyle karşılaştırıldığı bütüncül çoklu durum deseninden faydalanılmıştır.

Bütün bunlara ek olarak araştırmada, iki ülkenin öğretim programlarının amaç, içerik, öğretmeöğrenme süreçleri ve değerlendirme boyutlarının incelenmesini ve bunların karşılaştırılmasını amaçlandığından çalışmada karşılaştırmalı eğitimde kullanılan yatay yaklaşım esas alınmıştır. Yatay yaklaşımda sistemlerin birbirinden bağımsız ve bir arada bütün etkenleri incelenir (Ültanır, 2000).

\section{Örneklem}

Nitel araştırma yöntemlerinde daha çok kullanılan, geniş bir içeriğe sahip olan konuların detaylı bir şekilde araştırılmasına imkân tanıyan ve amaçlı örneklemenin çeşitlerinden olan kolay ulaşılabilir durum örneklemesi kullanılmıştır. Bu çeşit örneklemeler araştırmaya hız ve pratiklik kazandıran, araştırmacının yakın olan ve erişilmesi kolay olan bir durumu seçtiği, çoğu zaman araştırmacının diğer örnekleme yöntemlerini kullanma olanağının bulunmadığı durumlarda kullanılır (Yıldırım ve Şimşek, 2011). Bu nedenle araştırmanın örneklemini Azerbaycan Cumhuriyeti'nde 2016-2017 eğitim öğretim yılında uygulanan 7. sınıf coğrafya dersi öğretim programı ve ders kitabı ile Türkiye Cumhuriyeti'nde 2016-2017 eğitim öğretim yılında uygulanan 7. sınıf sosyal bilgiler dersi öğretim programı ve ders kitabı oluşturmaktadır.

\section{Veri Toplama Teknikleri}

Araştırmada, nitel araştırma yöntemlerinden olan doküman incelemesi kullanılarak Azerbaycan'da 7. sınıf düzeyinde okutulan coğrafya ders kitabı ve öğretim programı ile Türkiye'de 7. sınıflara okutulan sosyal bilgiler ders kitabı ve öğretim programı incelenmiştir. $\mathrm{Bu}$ araştırmada doküman incelemesi, Azerbaycan ve Türk öğretim programları ve ders kitapları olmak üzere araştırma kapsamındaki yazılı materyallerin çeşitli ölçütler ekseninde derinlemesine incelenmesi, tasnif edilmesi ve bütüncül şekilde ortaya konmasına dair izlenen süreçte kullanılmıştır.

Çalışma için öncelikle her iki ülkenin eğitim sistemlerine ilişkin bilgiler basılı kaynaklardan ve Azerbaycan Millî Eğitim Bakanlığı resmi internet sayfasından faydalanılarak incelenmiş ve karşılaştırmalı olarak analiz edilmiştir. Ardından Türkiye'de 7. sınıf sosyal bilgiler dersi 
coğrafya konuları ile Azerbaycan 7. sınıf coğrafya dersinin öğrenme alanları ve kazanımlar açısından benzer ve farklı yönlerini belirlemek için her iki ülkenin öğretim programları incelenmiştir. Son olarak Türkiye'de 7. sınıf sosyal bilgiler ders kitabı ile Azerbaycan 7. sınıf coğrafya ders kitabının incelenmesi için ders kitapları temin edilip, fiziksel ve eğitsel özellikleri; baskı kalitesi, bilginin sunumu, görsel öğeler ve ölçme değerlendirme açısından karşı1laştırılmıştır.

\section{Verilerin Analizi}

$\mathrm{Bu}$ araştırma da yazılı bir araç olan ders kitabı üzerinde çalışıldığı için değerlendirme de nitel bir veri toplama yöntemi olan doküman analizinin veriyi analiz etme yolu üzerinden yapılmıştır. Dokümanların tek başına bir araştırmanın veri setini oluşturduğu durumlarda, araştırmacılar dokümanları analiz ederken; eldeki verilerden örneklem belirleme, kategori oluşturma, analizin birimini tespit etme ve son olarak sonucu nicel hale getirme şeklinde basamak haline getirebilirler (Yıldırım ve Şimşek, 2011). Çalışmamızda Türkiye ve Azerbaycan ile ilgili, resmi internet siteleri ve basılı kaynaklardan elde edilen veriler sinıflandırılarak benzer ve farklı yönler tespit edilmiştir. Bu verilere dayalı olarak ilk önce her iki ülkenin eğitim sistemlerine ilişkin veriler toplanarak karşılaştırılmıştır. Daha sonra Türkiye'de 7. sınıfta okutulan sosyal bilgiler dersi coğrafya konuları ile Azerbaycan'da aynı sınıf düzeyinde okutulan coğrafya derslerinin öğrenme alanlarına ait veriler ile adı geçen derslere ait ders kitaplarının görsel açıdan incelenmesi sonucu ulaşılan veriler tespit edilmiştir. Tespit edilen veriler karşılaştırılarak ulaşılan sonuçlar çoğunlukla nitel olmak üzere nicel olarak da rapor edilmiştir.

\section{BULGULAR VE YORUM}

\section{Türkiye Cumhuriyeti ve Azerbaycan Cumhuriyeti'nin genel özellikleri}

\section{Türkiye Cumhuriyeti'nin genel özellikleri}

Türkiye Cumhuriyeti, Kuzey Yarımkürede yer alan Anadolu ve Trakya toprakları aracılığıyla Avrupa ve Asya kıtalarını birleştiren bir konumda kurulmuştur. Kuzeyinde Karadeniz, batısında Ege ve güneyinde Akdeniz olmak üzere üç tarafı denizlerle çevrilidir. Ayrıca İstanbul ve Çanakkale boğazları arasında kalan Marmara denizi de önemli bir geçiş noktasıdır. Çok eski çağlardan itibaren önemli ticaret yolları üzerinde bulunması, verimli arazileri ve yeterli su kaynakları nedeniyle Anadolu coğrafyası birçok medeniyet tarafından tercih edilmiştir.

TÜİK verilerine göre Türkiye nüfusu 31 Aralık 2018 tarihi itibarıyla 82 milyon 3 bin 882 kişi olmuştur. Türkiye'de ikamet eden nüfus 2018 yılında, bir önceki yıla göre 1 milyon 193 bin 357 kişi artmıştır. Erkek nüfusun oranı \%50,2 (41 milyon 139 bin 980 kişi), kadın nüfusun oranı ise \%49,8 (40 milyon 863 bin 902 kişi) olarak gerçekleşmiştir. Yıllık nüfus artış hızı 2017 yılında \%o12,4 iken, 2018 yılında \%o14,7 olmuştur. Ülke nüfusunun \%92,3'lik büyük bir kesimi il ve ilçe merkezlerinde yaşarken \% 7,7'luk kesim kırsal alanda yaşamaktadır. (Adrese Dayalı Nüfus Kayıt Sistemi Sonuçları, 2018). Türkiye'de yaşayan etnik gruplarla ilgili olarak yapılan araştırmalara göre ülkemizde Arnavut, Azeri, Arap, Boşnak, Çerkez, Çingene, Gürcü, Hemşinli, Laz, Pomak, Süryani ve Zaza gibi pek çok etnik grup yaşamaktadır.

Türkiye, özel sektörün etkili olduğu, devletin ise kontrol mekanizması olduğu, bir serbest piyasa ekonomisine sahiptir. Türkiye ekonomisindeki gelişmeyi dört önemli avantaja borçludur; ülkemizin alanının büyüklüğü, farklı iklim özellikleri ve buna bağlı olarak ürün çeşitliliği, ülke nüfusunun fazla olması ve ulaşımın gelişmesi, bu dört önemli unsur olarak gösterilebilir (Doğanay ve Çavuş, 2013). Türkiye ekonomisinde başta turizm ve madencilik 
olmak üzere tarım ve hayvancılıkta önemli bir paya sahiptir. Enerji ihtiyacının büyük bir kısmını komşularından ithal etmektedir.

Türkiye Cumhuriyeti 1982 Anayasasına göre; Türkiye'nin yönetim biçimi cumhuriyettir. Türkiye Cumhuriyeti, Mustafa Kemal Atatürk liderliğinde 1923 yılında kurulmuştur. Resmi dili Türkçe olan laik, demokratik, sosyal bir hukuk devletidir. Güçler ayrılığı ilkesi esastır. Türkiye, 1937 yllında anayasaya dâhil ettiği laiklik ilkesi gereğince din ve devlet işlerini birbirinde ayırmıştır. Cumhuriyetin ilk yıllarında dini propaganda yapılarak isyan hareketlerinin yaşanması dinin devlet kontrolünde olması gerektiğini kanıtlamış, bu nedenle dini kuruluşların devlet kontrolünde olmasına karar verilmiştir. Dini yapı konusunda en somut bilgi; Diyanet İşleri Başkanlığının TÜİK'e yaptırdığı araştırmadır. Bu araştırmanın sonuçlarına göre; Türkiye'de yaşayanların yüzde 99,2'si kendisini Müslüman olarak tanımlamaktadır. Ayrıca binde 4'ü başka bir din mensubu, binde 5'i ise bu soruya yanıt vermemiştir (Türkiye'de Dini Hayat Araştırması, 2014).

\section{Azerbaycan Cumhuriyeti'nin genel özellikleri}

Azerbaycan, 18 Ekim 1991 senesinde bağımsızlığını kazanmıştır. Güneydoğu Kafkasya'da yerleşen Azerbaycan Cumhuriyeti'nin yüz ölçümü 86,6 bin km2, Nahçıvan $5.500 \mathrm{~km} 2$ ve Dağlık Karabağ 4.400 km2 dir. Başkenti Bakü'dür. Ülkenin 2018 verilerine göre nüfusu 9 milyon 898 bindir (Azerbaycan Devlet İstatistik Komitesi, 2018). Ülkede Azeriler dışında Rus, Ermeni, Dağıstanlı, Tatar, Ukraynalı, vb topluluklar da yaşamaktadır. Azerbaycan'ın en önemli şehirleri ise; Bakü, Sumgait, Mingeçaur, Lenkeran, Astara, Akdam, Şuşa ve Nahçıvan'dır (Oğan, 1992). Sınır komşuları İran, Rusya Federasyonu, Ermenistan, Türkiye ve Gürcistan'dır.

Azerbaycan demokratik, laik ve üniter bir yapıya sahiptir. Ülkeyi cumhurbaşkanı yönetmektedir. Mevcut para birimi yeni manattır. Azerbaycan petrol, doğal gaz, kurşun, çinko, bakır ve demir gibi doğal kaynaklara, buğday üzüm, pamuk, tütün, çay, sebze ve meyve gibi tarımsal ürünlere sahiptir (TİKA, Azerbaycan ülke raporu, 1993).

Ülkenin en önemli gelir kaynaklarını petrol ve tarım oluşturur. Azerbaycan'da iklim şartlarının elverişli olması tarım ürünlerinde çeşitliliğin artmasına neden olmuştur. Ayrıca nehirler üzerine yapılan barajlar ve sulama kanalları, tarım alanlarının genişlemesini sağlamıştır. Azerbaycan yer altı kaynakları bakımından çok zengin bir ülkedir. Ülkenin en büyük zenginliğini petrol ve doğalgaz oluşturur. Petrol ve doğalgazın haricinde demir, bakır, kurşun ve kaya tuzu da ülkenin önemli madenlerindendir. Özellikle SSCB'nin dağılmasından sonra petrol alanındaki çalışmalar hız kazanmış ve şu an çok önemli bir seviyeye ulaşmıştır. Azerbaycan ürettiği petrolün \% 70’ini ihraç etmektedir. (Özey, 2010).

Anayasa'ya göre Azerbaycan devleti demokratik, laik ve üniter bir Cumhuriyettir. Güçler ayrılığı ilkesi benimsenmiştir. Azerbaycan Anayasası "Başkanlık" sisteminin özelliklerini taşımaktadır. Yasama yetkisi Milli Meclis'e, yürütme yetkisi Cumhurbaşkanına, yargı yetkisi mahkemelere verilmiştir. Cumhurbaşkanı hem devletin hem de yürütmenin başıdır. Ayrıca "Ferman" adı verilen hukuki kararlar verme yetkisine sahiptir (Türkoğlu, 2015). 1995 tarihli Azerbaycan Anayasası'nda devletin "dünyeviliği" esastır ve 18. maddesine göre de; din ve devlet işleri birbirinden ayrıdır. Bütün dinî inançlar kanun karşısında eşittir. Bu ilke, devletin dini konularında esas kabul edilmiştir. Ayrıca devlet vatandaşın dini konulardaki sorun ve taleplerine karşı ilgili kurumlar aracılığıyla çözüm noktasında ilgilenmektedir. Farklı inanç ve etnik grupların var olduğu Azerbaycan'da, din ve vicdan hürriyetinin çok önemli bir yeri vardır. Azerbaycan nüfusunun yaklaşık \%96'sı İslam dininin mensubudur. İslam dini Azerbaycan'da 
hem Sünnilik hem de Şiilik olarak temsil olunmaktadır. Ülkede yaşayan Müslümanların \%65'i Şii, \%35'i ise Sünnidir. Şiiler yoğunluklu olarak Bakü etrafındaki köylerde ve ülkenin güneyindeki İran'la sınır olan bölgelerde yaşamaktadırlar. Sünniler ise ağırlıklı olarak ülkenin orta ve kuzey kısımlarında yerleşmişlerdir (Musayev, 2010).

\section{Türkiye Cumhuriyeti Ve Azerbaycan Cumhuriyeti'nin Ĕ̈itim Sistemlerinin Temel Özellikleri}

\section{Türkiye Cumhuriyeti'nin Ë̆itim Sisteminin Yapısı}

Türk eğitim sisteminde, merkezi sistem mevcuttur. Eğitim ve öğretim faaliyetleri devletin izni ve kontrolü altında yapılmaktadır. Bu yetki devlet adına Millî Eğitim Bakanlığg'nın denetimindedir. Millî Eğitim Bakanlığı, eğitim ile ilgili bütün hizmetleri gerçekleştirir (Tatlı, 2010). 1739 sayılı Millî Eğitim Temel Kanunu'na göre Türk Millî Eğitim Sistemi, Örgün ve Yaygın eğitim olmak üzere iki ana bölümden oluşmaktadır.

\section{Örgün ĕgitim}

Örgün eğitim; belli bir yaş grubunda bulunan bireylere, belli bir amaç doğrultusunda hazırlanan programlarla, okullarda düzenli olarak yapılan eğitim faaliyetidir. Örgün eğitim; okul öncesi, ilkokul, ortaokul, ortaöğretim(lise) ve yükseköğretim kurumlarından oluşmaktadır.

Okulöncesi Eğitim: İsteğe bağlı olarak 3 yaş, 4 yaş ve 5 yaş seviyesindeki çocukları kapsamaktadır. Okul öncesi kurumlar bağımsız anaokulları olarak açılabildikleri gibi, ihtiyaç halinde ilkokullara bağlı ana sınıfı olarak da açılabilmektedirler (MEB İstatistikleri, 20152016). Okul öncesi eğitimin amacı; çocukların bedensel, zihinsel, duygusal gelişimini sağlayarak iyi alışkanlıklar kazandırmak, onları ilkokula hazırlamak, koşulları elverişsiz çevrelerden gelen çocuklar için firsat eşitliği sağlamak, Türkçenin doğru ve güzel konuşulmasını sağlamaktır (Gedikoğlu, 2005, s. 71). 2011 y1lında okul öncesi eğitim zorunlu hale getirilmiş ve bu durum öğrenci sayısının artmasına neden olmuştur. Ancak 2012 yılında okul öncesi eğitim zorunlu olmaktan çıkarılmış isteğe bağlı hale getirilmiştir. Buna bağlı olarak öğrenci sayısında düşüş yaşanmıştır. Son yıllarda artan ihtiyaca bağlı olarak 2017-2018 eğitim öğretim yılında 22 ilde pilot olarak uygulanacak olan zorunlu okul öncesi eğitimin 2019 yılında tüm ülkeye yayılması hedeflenmektedir.

İlkögretim (ilkokul-ortaokul): MEB Okul öncesi ve ilköğretim kurumları yönetmeliğine göre; zorunlu ilköğretim çağı 6 yaş ve 13 yaş arasındaki çocukları kapsamaktadır. İlköğretimin (ilkokul-ortaokul) amacı; her Türk çocuğunun, millî ahlak anlayışına bağlı, gerekli bilgi ve becerilere sahip bir vatandaş olarak yetişmesini sağlayarak üst öğrenim kurumlarına hazırlamaktır. İlköğretimde eğitim yılının 180 günden az olmaması esastır (Tatlı, 2010). İlköğretim kurumları; 1997-1998 öğretim yılından 2011-2012 eğitim öğretim yılına kadar ilköğretim adı altında 8 yıllık mecburi eğitim olarak uygulanmıştır. 2012-2013 eğitim öğretim yılından itibaren ise dörder yıl süreli ve zorunlu ilkokul ile ortaokullardan oluşmaktadır. Ayrıca ortaokullarda öğrencilerin kendilerini geliştirebileceği, ortaöğretimi destekleyebilecek şekilde seçmeli ders uygulaması bulunmaktadır.

Ortaöğretim: Ortaöğretim; ortaokula dayalı, en az dört yıllık zorunlu eğitim veren genel, mesleki ve teknik öğretim kurumlarından oluşmaktadır. Ortaöğretimde en az dört yıl devam eden, zorunlu eğitim veren akademik eğitimle yükseköğretime hazırlayan "Genel Ortaöğretim", yükseköğretimin yanı sira belirli bir mesleğe yönelik eğitim veren "Mesleki ve Teknik Ortaöğretim" ve örgün eğitime devam edemeyip öğrenim çă̆ 1 dişına çıkan öğrenciler için 
uzaktan eğitim yoluyla yapılan "Açık Öğretim Lisesi” türlerinde eğitim verilmektedir. Türkiye'de öğrencilerin ilgi ve yetenekleri doğrultusunda 8. sinıf sonunda yapılan sinav sonucuna göre yerleştikleri ortaöğretim kademesinde faaliyet gösteren liseler; Anadolu lisesi, Fen lisesi, Sosyal bilimler lisesi, Güzel sanatlar lisesi, Spor lisesi, Anadolu imam hatip lisesi ve Meslek liseleri olarak türlere ayrılmıştır

Yüksekögrretim: Yükseköğretim kurumları ülkelerin gelişip büyümesi için bilimsel faaliyetlerin yapıldığı ve nitelikli insanların yetiştirildiği kurumlar haline gelmiştir. $\mathrm{Bu}$ yüzden de üniversiteler, ülkelerin geleceğine yön veren önemli kuruluşlar arasında yer almaktadır (Gedikoğlu, 2005). Yükseköğretim; ortaöğretime dayalı, en az iki yıllık yükseköğrenim veren eğitim kurumlarının tümünü kapsar.

\section{Yaygın eğitim}

MEB Yaygın Eğitim Kurumları Yönetmeliği’ne (2010) göre; Yaygın eğitim, örgün eğitimle beraber veya örgün eğitimin dışında düzenlenen eğitim faaliyetlerinin tümünü kapsar. Türkiye'de faaliyet gösteren bazı yaygın eğitim kurumları aşağıdaki listede gösterildiği gibidir.
a. Meslek Eğitim Merkezi
b. Kız Teknik Olgunlaşma Enstitüsü
c. Halk Eğitim Merkezi
d. Turizm Eğitim Merkezi
e. Bilim Sanat Merkezi
f. Rehberlik Araştırma Merkezi
g. Meslek Kursları
h. Yetişkinler Teknik Eğitim Merkezi
i. Özel Öğretim Kursları
j. Motorlu Taşıt Sürücüleri Kursu
k. Muhtelif Kurslar
1. Özel Eğitim ve Rehabilitasyon Merkezi
m. Özel Eğitim Okulu
n. Özel Etüt Eğitim Merkezi

\section{Azerbaycan Cumhuriyeti'nin Ë̆itim Sisteminin Yapısı}

Eğitimin basamakları ve düzeyleri arasında eğitim programlarının (kurikulumlarının) yerine getirilmesi süreci "Eğitim Hakkında Azerbaycan Cumhuriyeti Kanunu"na göre hazırlanmıştır. Kanunun 9. maddesine göre eğitim, "her türlü bilgi, beceri ve sorumluluk duygusu kazandıran, ileri uygarlığa, gelişmiş dünya görüşüne ulaştıran, Azerbaycan'ın özgürlüğü ve bağımsızlığ 1 için çalışan, halkın milli, ahlaki, hümanist, maddi ve manevi değerlerine bağl1, onları koruyan ve geliştiren, insan haklarına saygılı bireyler yetiştirme eylemi” olarak ifade edilmiştir (Akkuş ve Seferov, 2005). Azerbaycan Cumhuriyeti Bakanlar Kurulunun 2010 yılı 4 Haziran tarihli 104 numaralı kararı ile onaylandığı Eğitim Kanunu'nun 17. maddesi gereğince Eğitim Sisteminin yapısı Tablo 2'de görüldüğü gibi belirlenmiştir; 
Tablo 11. Azerbaycan Cumhuriyeti Eğitim Sistemi

\begin{tabular}{|c|c|}
\hline & Örgün Eğitim \\
\hline 1. Okul Öncesi Eğitim & \\
\hline 2. Genel Eğitim & $\begin{array}{ll}\text { a. } & \text { İlköğretim-4 yıl (I-IV sınıflar) } \\
\text { b. } & \text { Genel orta öğretim-5 yıl (V-IX sınıflar) } \\
\text { c. } & \text { Tam orta öğretim-2 yıl (X-XI sınıflar) }\end{array}$ \\
\hline 3. İlk Peşe İhtisas Eğitimi & \\
\hline 4. Orta İhtisas Eğitimi & \\
\hline 5. Yükseköğretim & $\begin{array}{ll}\text { a. } & \text { Bakalavriat (Lisans) } \\
\text { b. } & \text { Fen } \\
\text { c. } & \text { Doktora }\end{array}$ \\
\hline & II. $\quad$ Yaygın Eğitim \\
\hline 1. Mektebdenkenar Eğitim & $\begin{array}{ll}\text { a. } & \text { Çocuk yaratıcılık merkezi } \\
\text { b. } & \text { Teknik yaratıcılık merkezi } \\
\text { c. } & \text { Çevresel Terbiye ve Tecrübecilik Merkezi } \\
\text { d. } & \text { Genç Turistler ve Diyarşünaslık Merkezi (Turizm ve } \\
& \text { Etnoğrafya Merkezi) } \\
\text { e. } & \text { Mektebdenkenar Terbiye İşi Merkezi } \\
\text { f. } & \text { Çocuk-gençlik fiziksel hazırlık kulübü } \\
\text { g. } & \text { Estetik Terbiye Merkezi } \\
\text { h. } & \text { Çocuk-Gençler Satranç Okulu } \\
\text { i. } & \text { Çocuk-Gençlik Spor Okulu } \\
\end{array}$ \\
\hline
\end{tabular}

\section{Örgün eğitim}

Okul öncesi eğitim: Azerbaycan Cumhuriyeti Bakanlar Kurulunun 2010 yılı 4 Haziran tarihli 104 numaralı kararına göre; bu aşamada eğitim süresi 3 yıldır. 5 yaştan 6 yaşa kadar olan süre okula hazırlık aşaması olarak kabul edilir. Eğitim kanunu temelinde, okul öncesi eğitim öğrencilere basit iş alışkanlıklarını öğretir, zihinsel ve fiziksel gelişimleriyle ilgilenir, yetenek ve becerilerini ortaya çıkarır, estetik açıdan yetişmesini sağlayarak onları okula hazırlar (Türkoğlu, 2015). Azerbaycan Cumhuriyeti'nde okul öncesi eğitimde okula hazırlığın düzenleme kuralları ilgili yönetim kurumu tarafından belirlenir. Okulöncesi eğitim; çocukların ev işleri, cengâverlik, kahramanlık, vatanseverlik, koro şeklinde şarkı söyleme, Azericeyi doğru ve güzel konuşmalarını sağlama, halk edebiyatından şiirler okuma, özel metotlarla yabancı dilleri öğrenme, resim, müzik, iş becerisi, dans etme, yüzme, gibi çeşitli etkinliklerin de içinde bulunduğu, çocukların eğitimini kapsayan faaliyetler bütünüdür (Sadıgov, 2009).

Genel eğitim: Azerbaycan Cumhuriyeti'nde Genel Eğitimle ilgili (umumi tahsil) düzenlemeler Eğitim Kanunu'nun 19. maddesinde belirtilmiştir. Bu maddeye göre Azerbaycan Cumhuriyeti'nde genel eğitim 3 kademede verilmektedir; Bunlar ilkokul-4 yıl (I-IV sınıflar), genel orta öğretim-5 yıl (V-IX sınıflar) ve tam orta öğretim-2 yıl (X-XI sınıflar) şeklindedir.

Illkokul: Azerbaycan'da ilkokula başlama yaşı 6'dır. İlkokul kademesi 1-4. Sınıfları kapsamaktadır ve zorunludur. Genellikle İlkokula alınırken öğrencilerin ilgileri, hobileri, sevdikleri ve sevmedikleriyle ilgili form doldurularak kayıtları yapılmaktadır. İlkokuldaki derslerin çoğu tek öğretmen tarafından verilmektedir. Sadece müzik, yabancı dil ve resim dersleri farklı ögretmenler tarafından verilmektedir (Mammadov, 2008).

Genel orta ögretim: Azerbaycan'da ortaokul kademesi 5-9. sinıfları kapsamaktadır. Azerbaycan vatandaşlarının bu eğitimi alması zorunludur. Genel orta eğitimin amacı; eğitim alanların sözlü konuşma ve yazma becerisini, iletişim yetisini, eğitim programına dâhil olan konularda ve ayrıca dünya uygarlığının gelişimi hakkında yeterli bilgi ve becerilerini, modern 
bilgi ve iletişimden yararlanma kabiliyetini, olayları değerlendirme ve kendi geleceğine yön verme yeteneğini temin etmektir (Azerbaycan Eğitim Bakanlı̆̆ı, Eğitim Kanunu, 2010). Ortaokulu bitiren öğrenciler eğitimlerine lise de devam edebilecekleri gibi belirli sınavlarla güzel sanatlar okulunda, meslek okullarında ve meslek liselerinde de eğitimlerine devam edebilmektedirler. Sınavların yapılış şekil ve kuralları okulların yönetmenliği doğrultusunda belirlenmektedir (Azerbaycan Eğitim Bakanlığı, Eğitim Kanunu, 2010).

Tam orta ögretim: Azerbaycan'da ortaöğretim 10-11. sınıfları kapsar. Ortaöğretimini tamamlamış olan öğrenciler yükseköğrenimine devam edebilirler. Liseyi bitiren öğrencilere "Ortaöğretim Diploması" verilir. Bu diplomaya Azerbaycan'da "Atestat" denilir (Akkuş ve Seferov, 2005). Tam orta eğitim seviyesinde, eğitim alanların yeteneğinin geliştirilmesi, bağımsız yaşama ve meslek seçimine hazırlanması, aktif vatandaş olması, ulusal ve evrensel değerlere, insan haklarına ve özgürlüklerine saygılı bireyler olması, modern bilgi ve iletişim teknolojilerinden faydalanabilmesi, ekonomik bilgilerin esaslarına sahip olması ve yabanc1 dillerden en az birinde iletişim kurabilmesi amaçlanır (Azerbaycan Eğitim Bakanlığı, Eğitim Kanunu, 2009). Tam orta eğitim belgesi eğitimin bir sonraki basamakta sürdürülmesi için esas kabul edilir.

Illk peşe ihtisas-orta ihtisas ĕgitimi (meslek liseleri, meslek okullarl): Sovyetler döneminden günümüze teknik meslek eğitim hep kendi önemi korumuştur. Ülkedeki endüstriyel ve üretim alanları için mesleki eğitim mezunları her zaman büyük potansiyel oluşturmuşlardır (Mammadov, 2008). Azerbaycan'da genel eğitim zorunludur. Temel eğitim ve lise düzeyinden mezun olanlar mesleki okul seçme hakkına sahiptirler (Türkoğlu, 2015). Bu okullara zorunlu eğitimi bitiren sanata ilgili bireyler ile herhangi bir sanat icra edenlerden ihtisasını artırmak isteyenler veya değiştirmek isteyen öğrenciler kabul edilmektedir (Zamanov, 2014). Azerbaycan eğitim kanununa (2009) göre; İlk peşe-ihtisas eğitimi işgücü piyasasının ihtiyaçlarına uygun olarak, genel orta ögretim ve tam orta eğitim tabanında çeşitli sanatlar ve toplu meslekler üzere ihtisaslı işçi kadroların hazırlanmasını sağlar. Azerbaycan'da faaliyet gösteren İlk Peşe İhtisas eğitimi meslek lisesi düzeyinde, Orta İhtisas Eğitimi ise 2 yıllık Meslek Yüksek Okulu düzeyinde eğitim vermektedir.

Yüksek ögretim (Ali mektepler): Azerbaycan'da yükseköğretimin amac1; ülkenin ihtiyac1 doğrultusunda, çeşitli alanlardan olmak üzere, ilmi ve pedagojik seviyesi yüksek kadrolar yetiştirmek, bilimsel araştırmalar yapmak, bilgi ve yeteneklerini üretim alanlarında uygulamayı başarabilen, diş ilişkilerde aktif, kendilerine verilecek her türlü görevi üstlenebilecek yüksek ihtisaslı kadrolar yetiştirmektir (Sadıgov, 2009). Azerbaycan'da faaliyet gösteren yükseköğretim kurumları arasında; Akademi, Üniversite, Fakülte, Enstitü, Konservatuar, Meslek Yüksek Okulu ve İlmi Araştırma Kurumları bulunmaktadır. Yüksek düzeyde uzmanlaşmış bilimsel pedegojik kadro, toplumun ve iş pazarının ihtiyaçları göz önünde bulundurularak yükseköğretimde eğitilir (Türkoğlu, 2015).

Bakalavriat ĕgitim seviyesinde tam orta eğitim ve orta ihtisas eğitimi alanına ayrı ayrı ihtisasların eğitim programları üzerine yüksek eğitimli uzmanlar hazırlanır. Bakalavriatı bitiren mezunlara "lisans" yüksek meslek-ihtisas derecesi verilir. Bakalavriat eğitimi almış mezunların bilimsel araştırma ve çalışmalar yapabilmesi için ikinci kademe olan yüksek lisans eğitimine devam etmesi gerekmektedir.

Yüksek lisans eğitimi, İki kademeli eğitim kurumlarında "bakalavr" derecesi almış olan uzmanlardan başarılı olanlar arasından sınavla "magistratura" (yüksek lisans) öğrencisi alınır. 
Fakülte yönetim kurulunun kararı ile verilen, ikinci bilimsel derece, ihtisas derecesidir. Yüksek lisans eğitimi, öğrencilere herhangi bir ihtisas alanında bilimsel araştırma ve kendini geliştirme hakk1 verir. Yüksek lisans eğitiminin içeriği, düzenlenmesi ve "master" derecelerinin belirlenmesi ilgili yönetim organı tarafından belirlenir.

Doktora, üçüncü kademede gerekli sınavlardan sonra "magistir" unvanı olanlar doktora için bilimsel çalışmalarına devam ederler. Hazırladıkları tezleri kabul edilenlere fakülte yönetim kurulunca "doktor" ve "ilimler namzedi" (adayı) unvanı verilir. Tüm bunlar akademik unvanına erişilinceye kadar devam eder. Yüksekögretim kurumlarında, akademisyenlere bilimsel çalışmaları sonucunda doçent ve profesör gibi bilimsel unvanlar verilir. Azerbaycan'da şu an 53 adet Üniversite faaliyet göstermektedir.

\section{Yaygın eğitim}

Milli Eğitim Sisteminin özü olup, çocuk ve gençlerin ilgi, yetenek ve entelektüel seviyelerinin fiziki ve manevi yönden geliştirilmesi amacıyla belli plan ve programlar çerçevesinde yapılan bir eğitim faaliyetidir. Yaşam boyu öğrenme herkes için önemlidir. Azerbaycan'da eğitimin yeniden düzenlenmesine uygun olarak yaşam boyu kavramı milli uzmanlar tarafindan geliştirilip eğitim bakanlığı tarafından uygulanmıştır (Türkoğlu, 2015).

Mektebdenkenar ĕgitim (okul dışı eğitim): Azerbaycan'da yaygın eğitim, aileler, diğer örgün eğitim kurumları, çeşitli kurumlar ve ayrıca münferit vatandaşların katkılarıyla yürütülen geniş çaplı bir eğitim faaliyetleri kategorisinde yer almaktadır. Eğitim Kanununa (2009) göre Azerbaycan'da faaliyet gösteren yaygın eğitimin özel amac1; milletimizin kaybolmaya yüz tutmuş, sanat ve mesleklerini yaşatmaya dönük bilgi ve becerilerini geliştirmek, hızla gelişen teknolojiye ayak uydurabilecek insan gücü yetiştirmek, ülkeyi ekonomik ve teknolojik bakımdan ileriye götürebilecek bilgi ve tecrübeyi kazandırmak, vatandaşlara boş vakitlerini uygun bir şekilde değerlendirme beceri ve alışkanlıkları kazandırmaktır.

Azerbaycan'da faaliyet gösteren; Çocuk Yaratıcılık Merkezi, Teknik Yaratıcılık Merkezi, Çevresel Terbiye ve Tecrübecilik Merkezi, Genç Turistler ve Diyarşünaslık Merkezi (Turizm ve Etnoğrafya Merkezi), Mektebdenkenar Terbiye İşi Merkezi, Çocuk-Gençlik Fiziksel Hazırlık Kulübü, Estetik Terbiye Merkezi, Çocuk-Gençler Satranç Okulu ve Çocuk-Gençlik Spor Okulu yaygın eğitim kurumları arasında sayılabilir

\section{Türkiye'de 7. Sınıf Sosyal Bilgiler Dersi ile Azerbaycan'da 7.Sınıfta Okutulan Coğrafya Dersinin Öğrenme Alanları ve Üniteler Açısından Benzer ve Farklı Yönleri}

\section{Türkiye'de 7. Sınıf Sosyal Bilgiler Öğretim Programı}

Programın ünite yapısı, konuları ve kazanımları Sosyal bilgiler öğretim programı (2005) ve Ders kitabına göre şu şekildedir:

1. Ünite: İletişim ve İnsan İlişkileri

\section{Konular1:}

A. Bir arada yaşamanın temeli: İletişim

B. Kitle iletişimin hızı baş döndürüyor

C. Doğru bilgi almak hepimizin hakk1

D. Bana "özel”, başkalarına "gizli"

E. Anadolu'dan haber var 


\section{“Kazanimlar:}

I.İletişimi, olumlu olumsuz etkileyen tutum ve davranışlarl fark ederek kendi tutum ve davranışlarıyla karşılaştırır.

II.İnsanlar arasında kurulan olumlu ilişkilerde iletişimin önemini fark eder.

III.Insanlar arası etkileşimde kitle iletişim araçlarının rolünü tartışır.

IV.Doğru bilgi alma hakkl, düşünceyi açıklama özgürlüğ̈̈ ve kitle iletişim özgürlüğ̈̈u arasındaki bağlantıyı fark eder.

V.Kitle iletişim özgürlüğ̈̈ ve özel hayatın gizliliği kavramlarını, birbiriyle ilişkileri çerçevesinde yorumlar.

VI.Atatürk'ün iletişime verdiği öneme kanttlar gösterir.”

Birinci ünite genel olarak insan ilişkileri ve iletişim konusu çerçevesinde ele alınmış olup genel olarak iletişim, kitle iletişim araçları, doğru bilgi alma hakkı, özel hayatın gizliliği ve Milli mücadele döneminde iletişim araçları ve önemi gibi konular işlenmiş coğrafya konularına bu ünitede yer verilmemiştir.

2. Ünite: Ülkemizde Nüfus

Konuları:
A. Nüfusumuzun dağılış1
B. Nüfusumuzun özellikleri
C. Eğitim ve çalışma hakkı
D. Nedenleri ve sonuçları ile göç
E. Yerleşme ve seyahat özgürlüğü

"Kazanımlarl:

I.Görsel materyaller ve verilerden yararlanarak Türkiye'de nüfusun dağılışının neden ve sonuçlarını tartışır.

II.Tablo ve grafiklerden yararlanarak, ülkemiz nüfusunun özellikleri ile ilgili verileri yorumlar.

III.Eğitim ve çalışma hakkının kullanılması ile devletin ve vatandaşın bu konudaki sorumlulukların ilişkilendirir.

IV. Örnek incelemeler yoluyla göçün neden ve sonuçlarını tartışır.

V.Yerleşme ve seyahat özgürlügünü açılklar."

İkinci ünitede coğrafya konusu olarak nüfus ve göç konuları işlenmiş Türkiye Nüfus ve göçün özellikleri anlatılmış, vatandaşlık konusu olarak da eğitim ve çalışma hakkı ile yerleşme ve seyahat özgürlüğü konularına yer verilmiş.

3. Ünite: Türk Tarihinde Yolculuk

Konuları:

A. Anadolu'nun Türk yurdu oluşu

B. Osmanlı Devletinin kuruluşu

C. Osmanlı Devletinin yükselişi

D. Osmanlı'da hoşgörü ve birlikte yaşama kültürü

E. Osmanlı'nın ilk başkenti: Bursa

F. Osmanl1-Avrupa etkileşimi

G. Seyahatnamelerde Osmanlı kültürü 
H. Osmanlı Devletinde toplumsal ve ekonomik değişim "Kazanımlarl:

I.Türkiye Selçukluları döneminde Türklerin siyasal mücadeleleri ve kültürel faaliyetlerinin Anadolu'nun Türkleşme sürecine katkılarını değerlendirir.

II.Kanıtlara dayanarak Osmanlı Devleti 'nin siyasi güç olarak ortaya çıkışını etkileyen faktörleri açıklar.

III.Osmanlı Devleti'nin fetih ve mücadelelerini, Osmanlı'da ticaretin ve denizlerin önemi açısından değerlendirir.

IV.Osmanlı toplumunda hoşgörü ve birlikte yaşama fikrinin önemine dayalı kanıtlar gösterir.

V.Şehir incelemesi yoluyla, Türk kültür, sanat ve estetik anlaylşındaki değissim ve sürekliliğe ilişkin kanitlar gösterir.

VI.Osmanlı- Avrupa ilişkileri çerçevesinde kültür, sanat ve estetik anlayışındaki etkileşimi fark eder.

VII.Seyahatnamelerden hareketle Türk kültürüne ait unsurlarl örneklendirir.

VIII.Osmanlı Devleti'nde ıslahat hareketleri sonucu ortaya çıkan kurumlardan hareketle toplumsal ve ekonomik değişim hakkında çıkarımlarda bulunur."

Üçüncü ünite, tamamen tarih konularından oluşmaktadır. Bu ünitede Türklerin Anadolu'ya gelişi ve devamında Anadolu' da kurulan beylikler, Osmanlı Devleti'nin kuruluşu ve yükselişi, hoşgörü politikası, kültürü ve gerilme döneminde Avrupa ile etkileşim konuları işlenip coğrafya konularına yer verilmemiştir.

4. Ünite: Zaman İçinde Bilim

Konular1:

A. Bilimsel ve teknolojik gelişmeler nasıl başladı

B. Geçmişten günümüze yazı

C. Türk İslam uygarlığının bilimsel birikime katkıları

D. Avrupa uygarlığının bilimsel birikime katkıları

"Kazanimlarl:

I.İlk uygarlıkların bilimsel ve teknolojik gelişmelere katkılarına örnekler verir.

II.İlkyazı örneklerinden yola çıkarak yazının kullanım alanlarını ve bilgi aktarımındaki önemini fark eder.

III.Türk ve İslam devletlerinde yetişen bilginlerin bilimsel gelişme sürecine katkılarını değerlendirir.

IV.15-19.yüzyllar arasında Avrupa'da yaşanan gelişmelerin günümüz bilimsel birikiminin oluşmasina etkisini fark eder.

V.Tarihsel süreçte düşünceyi ifade etme ve bilim özgürlüklerini bilimsel gelişmelerle ilişkilendirir."

Dördüncü ünite, bilim ve gelişim konusu çerçevesinde yazının gelişimi, Türk İslam uygarlığı ve Avrupa uygarlığının bilime katkıları ile düşünce özgürlüğü gibi tarih konularından oluşmaktadır.

5. Ünite: Ekonomi ve Sosyal Hayat

Konuları:

A. Üretimde ve yönetimde toprak

B. Zenginlik kaynakları 
C. Tarihten günümüze üretim araçları

D. Vakıf medeniyeti

E. Nas1l meslek edindiler

F. Mesleğimi seçiyorum

"Kazanımlart:

I.Üretimde ve yönetimde topră̆ın önemini tarihten örneklerle açıklar.

II.Kaynakların, ürünlerin ve ticaret yollarının devletlerin gelişmesindeki önemine tarihten ve günümüzden örnekler verir.

III.Tarihten ve günümüzden örnekler vererek üretim teknolojisindeki gelişmelerin sosyal ve ekonomik hayata etkilerini değerlendirir.

IV.Vakıfların çalışmalarına ve sosyal yaşamdaki rolüne tarihten ve günümüzden örnekler verir.

V.Tarih boyunca Türklerde meslek edindirme ve meslek etiği kazandırmada rol oynayan kurumlart tanir.

VI.Eğitimin meslek edindirme hedefini kavrayarak ilgi ve yetenekleri doğrultusunda meslekî tercihlerine yönelik planlama yapar."

Beşinci ünitede, ağırlıklı olarak tarih konularından oluşmaktadır. Tarih konuları dışında vakıf kültürü ve meslek seçimi gibi vatandaşlık konularına da yer verilmiştir.

6. $\quad$ Ünite: Yaşayan Demokrasi

Konuları:

A. Türklerde yönetim ve egemenlik

B. Anayasadan gelen güç

C. Yönetimin gücü

D. Yönetime etki eden güçler

E. Okulda demokrasi

"Kazanımlarl:

I.Tarihsel süreçte Türk devletlerinde yönetim şekli ve egemenlik anlayışındaki değişim ve sürekliliği fark eder.

II.Anayasamızın 2. maddesinde yer alan Türkiye Cumhuriyeti Devleti'nin nitelikleri ile ilgili uygulamalara toplum hayatından örnekler verir.

III.Türkiye Cumhuriyeti Devleti'nin yönetim yapısını yasama, yürütme ve yargı kavramları çerçevesinde analiz eder.

IV.Siyasî partilerin, sivil toplum örgütlerinin, medyanın ve bireylerin, gündemi ve yönetimin karar alma süreçlerini ne şekilde etkilediğini örnekler üzerinden tartışır.

V.İçinde bulunduğu ĕgitsel ve sosyal faaliyetlerde işleyen süreçleri demokrasinin ilkeleri açısından analiz eder."

Altıncı ünitede tarih konusuyla başlayıp vatandaşlık konuları ile devam etmiş; Türklerde yönetim ve egemenlik anlayışı ile anayasa, güçler ayrılığı ve okulda demokrasi konularına yer verilmiştir.

7. Ünite: Ülkeler Arası Köprüler

Konuları:
A. I. Dünya Savaşı
B. Dünya alarm veriyor 
C. Küresel sorunlara bireysel çözüm

D. Ortak mirasın nöbetçileri

\section{"Kazanımlart:}

\section{I.20. Yüzyllın başında Osmanlı Devleti ve Avrupa ülkelerinin siyasî ve ekonomik} yapısıyla I. Dünya Savaşı'nın sebep ve sonuçlarını iliş̧kilendirir.

II.Küresel sorunlarla uluslararası kuruluşların kuruluş amaçlarını ilişkilendirir.

III.Küresel sorunların çözümlerinin yaşama geçirilmesinde kişisel sorumluluğunu fark eder.

IV.Düşünce, sanat ve edebiyat ürünlerinin, doğal varllkların ve tarihi çevrelerin ortak miras öğesi olarak yaşatılmasında insanlığın sorumluluğunun farkına varır."

Yedinci ve son ünitede, tarih konusu olan 1. Dünya Savaşı konusuyla başlayıp küresel sorunlar, bireysel sorumluluklar ve ortak mirası korumanın önemi konularına yer verilmiştir.

Genel olarak 7. sınıf sosyal bilgiler programında ağırlıklı olarak tarih konuları yer almış, coğrafya konularının tüm kazanımlar içerisindeki oranı \%23,07 dir.

\section{Azerbaycan'da 7. Sinıf Coğrafya Öğretim Programı}

Azerbaycan'da 7. sınıf coğrafya dersi tamamen coğrafya konularından oluşmaktadır. 7. sınıf coğrafya dersi program1; Azerbaycan Cumhuriyeti Bakanlar Kurulu'nun 2006 tarihli, 233 numaralı kararı ile "Azerbaycan Cumhuriyeti'nde genel eğitimin konsepti (Milli ProgramMüfredat) ismiyle hazırlanan belgeye dayalı olarak Coğrafya öğretim programında güncelleme yapılmıştır. Azerbaycan coğrafya öğretim programında sınıflar düzeyinde önce genel kazanımlar daha sonra ise alt kazanım diye adlandırabileceğimiz kazanımlar verilirken, "Coğrafi Mekân", "Doğa" ve "Toplum" konularından oluşan üç içerik esası dikkate alınarak kazanım listesi şu şekilde oluşturulmuştur; (Azerbaycan Cumhuriyeti Coğrafya Eğitim Program1, 2013)

Coğrafi Mekân; Coğrafya eğitiminde "coğrafi mekân” öğrencilerde küresel, bölgesel ve yerel ölçekte mekân anlayışını oluşturarak Güneş sisteminde Dünya'nın konumu ve ilgili olayların tahlilinin yapılmasına olanak sağlanılmaktadır. Öğrencilerin coğrafi koordinat sistemini iyi öğrenerek Dünya üzerindeki konumunu veya farklı bir noktanın konumunu tespit edebilmesi beklenilmektedir.

Doğa; Ortaokullarda "doğa" içeriği öğrencilerin yer küreyi doğal sistem olarak kavrayıp, doğa olaylarının gelişim aşamalarını anlamasına olanak sağlar. Öğrenciler doğal süreçlerin nedenlerini analiz eder, sonuçlarını açıklar, gelecekte yaşanabilecek doğa olaylarına ilişkin varsayımda bulunurlar.

Toplum; Ortaokullarda "toplum” içeriği ile öğrencilerin, dünya nüfusunun ırk, milli, dini, etnik yapısının çeşitliliğini anlamasına, diğer halkların yaşam tarzlarını tanımasına olanak tanır. $\mathrm{Bu}$ bilgiler onlarda halkların gelenek ve göreneklerine, kendine has özelliklerine hoşgörülü yaklaşım hissini yaratır ve onun esasında milli şuuru şekillendirir. Öğrenciler, ulusal ve uluslararası siyasi-ekonomik ilişkilerin insanların hayat seviyesine etkisini anlayıp, ekonomik gelişmenin yarattığı çevresel sorunların oluşum nedenlerini belirleyerek, doğal dengenin sürdürülmesinde küresel projelerin uygulamasında her bir bireyin katılımının önemini, dünyada 
çatışma bölgelerinin varoluş nedenlerini ve bunların çözümünde uluslararası kurumların rolünü değerlendirir.

$\mathrm{Bu}$ içerik esaslarına göre 7. sınıf coğrafya dersinin genel kazanımları şu şekildedir:

a. Dünya ile ilgili yeni keşiflere dair bilgiler toplar ve bu keşiflerin coğrafya biliminin gelişimindeki rolünü analiz eder;

b. Kartografik çizimler üzerinde çeşitli hesaplama çalışmaları yapar, bilgiler toplar, onları pratik olarak uygular

c. Gökyüzü cisimlerinin karşılıklı etkileşimini ve bu etkileşimin coğrafi sonuçlarını ilişkilendirir;

d. Coğrafi tabakada meydana gelen olay ve süreçleri ilişkilendirir.

e. Dünya nüfusunun dağılımını inceleyerek ülkeleri büyüklügüne göre gruplandırır

f. Dünya ekonomisinin modern modelini ülkeler bazında ayırır.

Ortaokul 7. sınıf coğrafya dersinin alt kazanımları olarak içerik esasına göre kazanımlar ise şu şekildedir.

Coğrafi Mekân içerikli kazanımları:

A. Coğrafi keşifler sonucunda toplumda ve haritada meydana gelen değişimlere ait bilgi ve becerilere sahiptir.

a. Keşif ve araştırma sonuçlarını harita üzerinde değerlendirir.

B. Dünya'nın Güneş sistemindeki konumu ve hareketlerine ilişsin bilgi ve becerilere sahiptir.

a. Gök cisimlerinin birbirine etkisini ve coğrafi sonuçlarını ilişkilendirir.

b. Yer kürenin hareketinin sonuçlarına dair basit hesaplamalar yapar.

C. Kartografik çizimler üzerinde bilgi ve becerilere sahiptir.

a. Kartografik öğeleri ayırır.

b. Kartografik öğelere göre basit hesaplamalar yapar.

Doğa içerikli kazanımlar:

A. Coğrafi tabakada meydana gelen olayların eko-coğrafi sonuçlarını benimsediğini göstermektedir.

a. Yer yüzeyinde depremlerin varoluş nedenlerini yorumlar.

b. Fiziki haritaları analiz eder.

c. Atmosferde meydana gelen olay ve gelişmelerin anakara ve okyanuslara etkisini yorumlar.

d. Hava öğelerine dair basit hesaplamalar yapar.

e. Dünya Okyanusu ve kara sularının fiziksel-coğrafi özelliklerini yorumlar.

f. Haritada dünya okyanusunun bölümlerini kaydeder.

g. Biyosferin iç bileşenlerinin karşılıklı ilişkisini anlatır.

h. Toprak tiplerini harita üzerinde analiz eder. 
Toplum içerikli kazanımlar:

A. Dünya nüfusunun çeşitliliğinin nedenlerine dair bilgi ve beceriler kazandığını göstermektedir.

a. Nüfusun bölgeler bazında dağılımını yorumlar.

b. Haritada insanların sık yerleştiği arazileri belirtir.

B. Toplumla ekonominin karşılıklı ilişkisine ait bilgi ve beceriler kazandığını göstermektedir.

a. Ülkeleri toplumsal özelliklerine göre analiz eder.

b. Harita üzerinde ülkeleri toplumsal özelliklerine göre gruplandırır.

c. Dünya ekonomisine etki eden doğal ve ekonomik faktörleri yorumlar.

d. Dünya ekonomisinin modern modelinin şemasını hazırlar.

e. Doğanın bilinçsizce kullanılması sonucunda ekolojik sıkıntı yaşayan bölgelerinin listesini düzenler.

Azerbaycan 7. Sınıf Coğrafya dersi programı ve ders kitabına göre; dersin içeriğinde bulunan bölümler ve konular ise şu şekildedir:

Giriş:

- Kitalar ve okyanuslar coğrafyasi.

- Yer kürenin öğrenilmesinin aşamaları.

- Kitalarin haritaları.

1. Bölüm:

- Dünyanın Özellikleri

- Dünya güneş sisteminin gezegenidir.

- Dünyanın kendi ekseni ve güneşin etrafındaki hareketi

- Yer Kabuğu ve Dağlar

- Litosfer ve oluşumu

- Yerin yapis1

- Dünyanın en büyük dağları - Atmosfer ve İklim

- Atmosfer ve önemi. Güneş radyasyonu

- Yeryüzünde hava sıcaklığının ve atmosfer basıncının dağıtılması ve daimi rüzgârlar.

- Yeryüzünde yağışların dağılişı

- İklimi oluşturan faktörler - Dünya Okyanusları

- Dünya okyanusu

- Sakin okyanus

- Atlantik okyanusu

- Hint okyanusu

- Kuzey buz okyanusu - Coğrafi Tabaka

- Coğrafi tabaka

- Doğal bölgeler 
2. Bölüm:

$$
\text { - Kitalar }
$$

- Avrasya
a. Avrasya kıtasının coğrafi konumu
b. Avrasya kıtasının kıyı hatları ve onu çevreleyen okyanus ve denizler
c. Avrasya kitasinın incelemesi
d. Avrasya kıtasının jeolojik oluşumu
e. Avrasya kıtasının arazi yapısı ve madenleri
f. Avrasya kıtasının iklimi
g. Avrasya kıtasının iklim kuşakları ve iklim tipleri
h. İç suları
i. Doğal bölgeleri

- Avrupa
a. Coğrafi konumu ve kıyı hatları
b. Bat1 Avrupa
c. Doğu Avrupa

- Asya
a. Coğrafi konumu kıyı hatları, Doğu Asya
b. Güneydoğu ve Güney Asya
c. Güneybatı Asya
d. Merkezi ve Kuzey Asya

- Kuzey Amerika
a. Coğrafi konumu ve sahil hatları
b. Arazi yapisı ve madenleri
c. İklimi
d. İç suları
e. Doğal bölgeleri
f. Toplumsal ve siyasi haritası

- Güney Amerika
a. Coğrafi konumu ve sahil hatları
b. Arazi yapısı ve madenleri
c. İklimi
d. İç suları
e. Doğal bölgeleri
f. Toplumsal ve siyasi haritası

- Afrika
a. Coğrafi konumu ve sahil hatları
b. Arazi yapısı ve madenleri
c. İklimi
d. İç suları
e. Doğal bölgeleri
f. Toplumsal ve siyasi haritasi

- Avustralya ve Okyanusya
a. Coğrafi konumu, bulunuş (keşif) tarihi, arazi yapısı ve madenleri
b. İklimi ve iç suları
c. Doğal bölgeleri ve organik dünyası
d. Okyanusya

- Antarktika 
a. Coğrafi konumu, keşfi ve incelemesi
b. Doğal düzeni organik dünyası

Görüldüğü üzere Azerbaycan'da 7. sınıf coğrafya müfredatında ayrıntılı bir şekilde dünyanın oluşumu, yer kürenin özellikleri, atmosfer ve iklimin yanı sıra kıtalar ve okyanuslar işlenmektedir.

\section{Türkiye'de 7. Sınıf Sosyal Bilgiler Ders Kitabı ile Azerbaycan'da 7.Sinıfta Okutulan Coğrafya Ders Kitabının Görsel Açıdan Benzer ve Farklı Olan Özellikleri}

\section{Türkiye'de 7. Sınıfta Okutulan Sosyal Bilgiler Ders Kitabının Görsel Açıdan Fiziksel ve Ĕgitsel Özellikleri}

Kapak tasarımı; ön dış kapakta açık mavi zemin üzerinde, dersin adı sınıf düzeyi ve orta kısımda arka kapaktan bağımsız bir şekilde, her biri farklı bir renkte olan insan figürleri ve onların üzerinde yine figürlerle aynı renkte içi boş konuşma balonları bulunmaktadır. Kapağın alt bölümünde ise yayınevinin adı ve amblemi yer almaktadır. Sırt yazısı; kitapta sırt yazısı olarak ders adı ve sınıf düzeyi yazmaktadır. Kitap boyutu; kitap $(27,5$ x 19,5) cm ebatlarındadır. Kitap cildi; Kapak ve sayfalar tutkal kullanılarak birleştirilmiş, kapak sayfası kalın karton kâğıttan malzeme kullanılarak basılmıştır.

Baskı kalitesi; kitabın baskısında ve sayfalarda kir ve leke bulunmamaktadır. Kapak kalın karton kâğıda basılmış iç sayfalar kalın kâğıda basıldığı görülmektedir. Baskı kalitesi ve ciltleme ve iç sayfalarda kullanılan yazı ve resim kalitesi açısından kaliteli bir basım olduğu söylenebilir; tutkalla birleştirilen sayfalar sağlam yapıldığı için kolaylıkla birbirinden ve kapaktan ayrılmamaktadır.

Kitap toplamda 208 sayfadan oluşmaktadır. Kitabın, 3. sayfasında Türk Bayrağı ve İstiklal Marşı, 4. sayfasında Mustafa Kemal Atatürk'ün Gençliğe Hitabesi, 5. sayfasında Mustafa Kemal Atatürk'ün portresi, 6 ve 7. sayfalarında içindekiler bölümü, 8 ve 9. sayfalarda kitabın kullanımına dair tanıtım șeması, 10 ile 185. sayfalar arasında üniteler, 186 ile 191. sayfalar arasında sözlük, 192 ile 201. sayfalar arasında kaynakça, 202 ile 203. sayfalarda öğrenci çalışma kitabı kaynakçası, 204 ile 206. sayfalar arasında kronoloji bölümü, 207. sayfada Türkiye idari haritası ve son sayfa olan 208. sayfada Türk Dünyası haritası bulunmaktadır. Kitabın içeriğinde yer alan konular Sosyal Bilgiler dersi adı altında; Tarih, Coğrafya ve Vatandaşlık Bilgisi konularından oluşmaktadır. Kitabın sayfa yapısında; sağ, sol, alt ve üst kenar boşlukları hemen hemen her sayfa için aynı oranda düzenlenerek sayfa bütünlügü korunmuştur. Genel olarak; üst boşluk $2.8 \mathrm{~cm}$, sağ ve sol boşluk $2.4 \mathrm{~cm}$ ve alt kenar boşluğu olarak $1.6 \mathrm{~cm}$ bırakılmıştır. Sayfa numaraları sağ ve sol alt köşelerde yer almaktadır. Ayrıca sayfaların sağ alt kenarlarında o sayfada geçen konu ile alakalı öğrenci çalışma kitabında yer alan çalışmanın bulunduğu sayfa numarası belirtilmektedir.

Görsel öğe olarak ünite ve konuların içeriği ile alakalı çok sayıda harita, resim, şekil, grafik ve görsel paragraflar ile bir bütünlük içerisinde kullanılmıştır. Ölçme ve değerlendirme olarak; her konunun başında dikkat çekici ve öğrenciyi düşünmeye sevk edecek bir soru ve konu içerisinde öğrencinin düşüncesini ortaya koyabileceği sorular yer almaktadır. Ayrıca her ünitenin sonunda ünite değerlendirme çalışması bulunmaktadır. Bu çalışma içerisinde; çoktan seçmeli sorular, doğru-yanlış etkinliği, eşleştirme etkinliği ve birkaç cümle ile cevaplanabilecek klasik sorular yer almaktadir 
Azerbaycan'da 7. Sınıfta Okutulan Coğrafya Ders Kitabının Görsel Açıdan Fiziksel ve Eğitsel Özellikleri

Kapak tasarımı; Azerbaycan' da okutulan 7. sınıf coğrafya ders kitabı ön dış kapakta mavi zemin üzerine; ders adı, sınıf düzeyi ve arka kapakla bir bütün halinde yer alan bir dünya haritası bulunmaktadır. Kitap cildi; Kapak ve sayfalar tutkal kullanılarak birleştirilmiş, kapak sayfası kalın kuşe kâğıttan malzeme kullanılarak basılmıştır. Baskı kalitesi; kitabın baskısında ve sayfalarda kir ve leke bulunmamaktadır. Kapak kalın kuşe kâğıda basılmış iç sayfalar ise ince kâğıda basıldığı için 1şığa tutulduğunda arka sayfanın baskısı görülmektedir. Baskı kalitesi ve ciltleme açısından çok kaliteli bir basım olduğu söylenemez; tutkalla birleştirilen sayfalar kolaylıkla birbirinden ve kapaktan ayrılmaktadır.

Kitap toplamda 240 sayfadan oluşmaktadır. İlk sayfalarında 3. sayfa ile 18. sayfa arasında "giriş" bölümü, 19. sayfa ile 79. sayfa arasında "I. Bölüm", 80. sayfa ile 224. sayfa arasında ise "II. Bölüm” bulunmaktadır. Kitabın son kısımlarında ise; 225 ve 232. sayfalar arasında ekler başlığı altında; dünyanın yüksek dağları, düzlükleri, denizleri, körfezleri, boğazları, adaları, nehirleri ve gölleri ile ilgili bilgilere yer verilmiştir. 233-235. sayfalarda sözlük bölümü bulunmaktadır. 236-237. Sayfalarda ise kitapta yer alan konulara ayrılacak ders saatlerini içeren bir plan yer almaktadır. 238-239. sayfalarda içindekiler bölümü bulunurken, 240. ve son sayfada üst kısımda kitap yazarlarının isimleri, kitap künyesi, teknik ekipte yer alanların isimleri ve görevleri, alt kısımda ise kitabın basımı ile ilgili teknik bilgiler ile yayınevinin adresi yer almaktadır. Kitabın içeriğinde yer alan konular tamamen coğrafya konularından oluşmaktadır.

Kitabın sayfa yapısında; sağ, sol, alt ve üst kenarlardan bırakılan boşluklar hemen hemen her sayfa için aynı oranda düzenlenmiştir. Genellikle üst, sağ ve sol boşluk olarak $2 \mathrm{~cm}$, alt boşluk olarak ise $3 \mathrm{~cm}$ boşluk bırakılarak sayfa yapısı konusunda bütünlük oluşturulmuştur. Sayfa numaraları sağ ve sol alt kenarlarda mavi şerit içerisinde yer almaktadır. Görsel öğe olarak ünite ve konuların içeriği ile alakalı çok sayıda harita, resim, şekil, grafik ve görsel paragraflar ile bir bütünlük içerisinde kullanılmıştır. Ölçme ve değerlendirme açısından, konu anlatılırken konu içerisinde yer yer düşünmeye ve tartışmaya dayalı soru kutucukları kullanılmıştır. Ayrıca konu sonlarında birkaç kısa soru ile ölçme değerlendirme yapılmıştır. Bunun dışında ölçme ve değerlendirmeye yönelik etkinlik veya değerlendirme çalışması yer almamaktadır.

\section{SONUÇLAR ve ÖNERILER}

\section{İki Ülkenin Ĕgitim Sistemleri ile İlgili Ulaşılan Sonuçlar}

Her iki ülkenin eğitim tarihinde bağımsızlık yılları önemli dönüm noktası olmuştur. Türkiye Cumhuriyeti'nin 29 Ekim 1923'te kuruluşu ile Azerbaycan Cumhuriyeti'nin 1991'de bağımsızlığını kazanması eğitim sistemlerinde değişime gidilmesi ile sonuçlanmıştır. Türk eğitim sistemi Selçuklu ve Osmanlı Devletleri zamanında Türk-İslam kültürü çerçevesinde şekillenmiş, Türkiye Cumhuriyeti'nin kurulması ile milli kimliğini koruyarak bazı değişikliklere uğramıştır. Bu değişikliklerinin en önemlisi Osmanlıca harflerin kullanımının kaldırılarak latin harflerine geçilmesi olmuştur.

Azerbaycan eğitim sistemi ise daha köklü değişikliklere uğramıştır. 1830'lu yıllarda Rusların Azerbaycan'ı işgali üzerine Azerbaycan'da eğitim sisteminde Rus kültürü ve Hıristiyanlık etkili olmaya başlamıştır. Bu baskı 1991'de Azerbaycan'ın bağımsızlığını ilan etmesine kadar devam etmiş, bağımsızlığın ilanı sonrasında ise köklü değişiklikler yapılarak Azerbaycan eğitim sistemi millileşmeye başlamıştır. 
Her iki ülkenin eğitim sistemi genel amaçlar yönüyle hemen hemen aynı özellikleri barındırmaktadır. Fırsat eşitliği, etkin vatandaşlar yetiştirme, yöneltme ve çağdaş eğitim gibi amaçlar her iki ülkenin genel amaçları arasında yer almaktadır. İki ülkenin eğitim sistemleri, kendi anayasaları ve uluslararası hukuk çerçevesinde güvence altına alınmıştır. Her iki ülkede de bu görev devlet tarafindan üstlenilmiştir.

Her iki ülkenin eğitim dili Türk dilidir. Ancak Azerbaycan'da halkın \%10'u azınlıklardan oluşmaktadır ve Türkiye'nin aksine anayasalarında belirtilen devlet standartları, Türk dili ve edebiyatı, Azerbaycan tarihi ve Azerbaycan coğrafyası öğretimi şartlarına bağlı olarak kendi dillerinde eğitim görebilirler. Türkiye Cumhuriyeti'nde ise 1982 Anayasası'nın 42. maddesine göre eğitimde Türkçeden başka hiçbir dil ana dil olarak okutulamaz ve öğretilemez. Ancak son yıllarda bu konuda seçmeli dersler adı altında yerel ağız ve lehçelerin okullarda öğretilmesine geçilmiş birçok ağız ve lehçe bu şekilde vatandaşlara istekleri doğrultusunda öğretilmeye başlanmıştır. İki ülkenin eğitim sistemlerinin yapısal düzenlemeleri çıkarılan kanunlarla düzenlemiştir. İki ülkenin eğitim yapısı genel olarak; örgün eğitim ve yaygın eğitim temelinde oluşturulmuş ve sistem içerisinde hem devlet hem de özel sektör yer almıştır.

Okul öncesi eğitim her iki ülkede de ilkokula hazırlık anlamında değerlendirilmiştir. Azerbaycan'da okul öncesi eğitim 3 yaşından itibaren başlar ve 5 yaşına kadar devam eder. Ögrenciler 5 yaşına geldiklerinde ise okula hazırlık adı altında zorunlu olarak devamları istenir. Türkiye'de ise okul öncesi eğitim 3 yaş ile 5 yaşın sonuna kadar devam eder. Türkiye'de okul öncesi eğitim, 2017-2018 eğitim öğretim y1lı itibariyle, 5 yaşında zorunlu hale getirilmeye çalış1lmaktadır.

Eğitim kademesi olarak Azerbaycan'da Türkiye'den farklı olarak; genel eğitim (Umumi Tahsil) adı altında 3 kademe yer almaktadır. İlkokul (I ve IV. sınıflar), 6 yaşında başlar, 4 yıl süreli ve zorunludur. Genel orta öğretim (V ve IX. sınıflar), 5 yıl süreli ve zorunludur. Tam orta öğretim (X ve XI. sinıflar), 2 yıl süreli ve zorunludur. Genel eğitimde ilk 11 yıl zorunludur, eğitim her yıl 1 Ekim'de başlar ve 31 Mayıs'ta sona erer. İki yarıyıl olarak planlanmıştır. Ders yılı içerisinde; 5 gün sonbahar (16-20 Kasım), 5 gün kış (27-31 Ocak) ve 5 gün de ek (1-5 Mayıs) tatil yapılır. Ders süreleri 30 dakika teneffüsler ise 10 dakikadır. Bazı derslerde 3 dakika ek dinlenme süresi daha verilir. Genel olarak ev ödevi verilmez ve sınıf mevcutları 30 kişiyi geçmemektedir.

Türkiye'de ise eğitim yapısı, İlkokul (I ve IV. sınıflar) 4 yıl sürelidir, 6 yaşında başlar ve zorunludur. Ortaokul (V. VIII. sinıflar), 4 yıl süreli ve zorunludur. Ortaöğretim (IX ve XII. sınıflar) 4 yıl süreli ve zorunludur. Bir başka deyişle Türkiye'de örgün eğitimin ilk 12 yılı zorunludur. Eğitim öğretim takvimi Millî Eğitim Bakanlığı tarafından bir önceki eğitim öğretim yılında belirlenir ve ilan edilir. Genel olarak 2 yarıyıl şeklinde eylül ayının 3. haftası başında başlar, haziran ayının 2. haftası sonunda biter. Ders yılı içerisinde 1. dönem genel olarak ocak ayının son haftası sona erer ve 15 günlük tatilin ardından 2. dönem başlar. Ders süreleri ilk ve ortaokullarda 40 dakika, tenefüsler 10 dakika, ortaöğretimde ise ders süresi 45 dakika tenefüsler ise 10 dakika olarak belirlenmiştir. Ev ödevi her kademede etkinlik, proje görevi vb. isimler altında verilmektedir. Türkiye'de Azerbaycan'a oranla nüfus miktarının fazla olması ve adrese dayalı nüfus kayıt sistemi uygulaması nedeniyle sınıf mevcudunda herhangi bir sınırlamaya gidilememektedir. Ancak sınıf mevcutları ortalama olarak 30 öğrenci sayısında tutulmaya çalışılsa da bazı bölgelerde yine de 40'ı aşmaktadır. 
Her iki ülke de hem anayasalarında hem de eğitim sistemlerinde laiklik ilkesini benimsemişlerdir. Fakat Türkiye'nin aksine Azerbaycan'ın dini yapısı nedeniyle okullarda bağımsız din dersi okutulmamaktadır.

Yüksek öğretim kademesindeki uygulama biçimi her iki ülkede de benzer özellikler taşımaktadır. Azerbaycan' da günümüzde 53 adet üniversite faaliyet gösterirken Türkiye'de 193 üniversite faaliyettedir.

Yaygın eğitim olarak Azerbaycan'da Mektebdenkenar (okul dışı) eğitim adı altında çocuk, genç ve yetişkin kademelerinde tamamlayıcı ve destekleyici kurslar düzenlenmektedir. Türkiye'de ise yaygın eğitim resmi ve özel kuruluşlar aracılığıyla yürütülmektedir. Hali hazırda Azerbaycan'da 368, Türkiye'de ise 12,194 yaygın eğitim kuruluşu bulunmaktadır. Türkiye'nin yaygın eğitim konusunda daha etkili olduğu görülmektedir.

\section{Türkiye’de 7. Sınıf Sosyal Bilgiler öğretimi ve Azerbaycan 7. Sınıf Cŏgrafya Ö̆̆retimi ile Ilgili Ulaşılan Sonuçlar}

Türkiye'de 7. sınıf düzeyinde uygulan sosyal bilgiler dersi tarih, coğrafya ve vatandaşlık konularını içermektedir. Dersin öğrenme alanları ve kazanımlarında ağırlıklı olarak tarih ve vatandaşlık konuları yer alırken coğrafya konularına ait kazanım oranı tüm kazanımlar içerisinde \%23.07'dir. Azerbaycan'da ise 7. sinıf düzeyinde tarih ve coğrafya konuları birbirinden bağımsız bir şekilde iki ayrı ders olarak okutulmaktadır. Karşılaştırmaya esas alınan 7. sınıf coğrafya dersi tamamen coğrafya konularından oluşmaktadır.

Öğretim programı ve ders kitabı düzenlenirken Türkiye'de ilk düzey olarak “Öğrenme Alanı” ardından ise "Ünite" başlıklarının altında konular yer almaktadır. Kazanımlar ise her öğrenme alanı için ayrı ayrı şekilde konular bazında hazırlanmıştır. Azerbaycan' da ise öğretim programı kapsamında konu düzeni ilk olarak "Bölümlere" ardında da "Alt Başlıklara" ayrılmaktadır. Kazanımlar ise sınıflar bazında her sınıf düzeyinde, her ders için "Coğrafi Mekân", "Doğa" ve "Toplum” başlıklarından oluşturulmuş ve ayrıntıya girilmemiştir.

Türkiye'de 7. sınıf sosyal bilgiler dersi haftada 3 saat olarak okutulmakta iken Azerbaycan 7. sınıf coğrafya dersi haftada 2 saat olarak okutulmaktadır. Türkiye'de 7. sınıf sosyal bilgiler dersinde yapılandırmacı yaklaşımın etkisiyle öğrenci merkezli bir tutumla öğrencinin bilgileye ulaşması hedeflenmiştir. Azerbaycan coğrafya ders kitaplarının ise bilgiyi çok yoğun bir şekilde içerdiği görülmüştür. Bilgi verici metinler öğrencilerin kendi fikirlerini oluşturmalarını güçleştirebilir, var olan bilgiyi sorgulamadan kabul etmesine neden olabilir. Azerbaycan 7. sınıf coğrafya dersi konularını Türkiye'de öğrenciler 9 ve 10 sınıf düzeyinde görmektedir.

\section{Türkiye'de 7. Sınıf Sosyal Bilgiler Ders Kitabı ve Azerbaycan 7. Sınıf Coğrafya Ders Kitabı Incelemesi ile Ulaşılan Sonuçlar}

Türkiye 7. sınıf sosyal bilgiler ders kitabının içeriği disiplinler arası bir yaklaşımla tarih, coğrafya ve vatandaşlık konularından oluşmaktadır. Ülke genelinde Millı̂ Eğitim Bakanlığı'nın izni ile birkaç yayınevinin ders kitabı, öğrenim alanları ve kazanımlara bağlı kalmak şartı ile kullanılabilmektedir. Azerbaycan 7. sinıf coğrafya ders kitabı ise tamamen coğrafya konularından oluşmaktadır. Azerbaycan'da ülke genelinde coğrafya ders kitabı olarak Eğitim Bakanlığı'nın izin verdiği tek bir kitap kullanılmaktadır.

Türkiye 7. sınıf sosyal bilgiler ders kitabında konuların sunumu sırasında kaynak sorgulatılması öğrenciler açısından kaynakça kullanımı konusunda olumlu bir etki oluşturmaktadır. 
Azerbaycan 7. sınıf coğrafya ders kitabında ise kaynakça bulunmaması kaynak sorgulatılması konusunda öğrenciler açısından olumsuz bir durum oluşturmaktadır.

Her iki kitapta, sayfalarda konu ile ilgili resim, grafik, şekil ve fotoğraflar bütünlük içerisinde yer almıştır. Türkiye 7. sınıf sosyal bilgiler ders kitabında; her konunun başında dikkat çekici ve öğrenciyi düşünmeye sevk edecek bir soru ve konu içerisinde öğrencinin düşüncesini ortaya koyabileceği sorular yer almaktadır. Ayrıca her ünitenin sonunda ünite değerlendirme çalışması bulunmaktadır. Bu çalışma içerisinde; çoktan seçmeli sorular, doğru-yanlış etkinliği, eşleştirme etkinliği ve birkaç cümle ile cevaplanabilecek açık uçlu sorular yer almaktadır. Azerbaycan 7. sınıf coğrafya ders kitabında ise; konu anlatılırken konu içerisinde yer yer düşünmeye ve tartışmaya dayalı soru kutucukları kullanılmıştır. Ayrıca konu sonlarında birkaç kısa soru ile ölçme değerlendirme yapılmıştır. Bunun dışında ölçme ve değerlendirmeye yönelik etkinlik veya değerlendirme çalışması yer almamaktadır.

Türkiye 7. sınıf sosyal bilgiler ders kitabının boyutları $(27,5 \times 19,5) \mathrm{cm}$ ebatlarındadır. Azerbaycan 7. sınıf coğrafya ders kitabı ise $(23,8 \times 16,5) \mathrm{cm}$ ebatlarındadır. Türkiye 7 . sinıf sosyal bilgiler ders kitabı 208 sayfadan oluşurken, Azerbaycan 7. sınıf coğrafya ders kitabı 240 sayfadan oluşmaktadır.

Her iki ülkenin ders kitapları baskı kalitesi olarak incelendiğinde; Türkiye 7. sınıf sosyal bilgiler ders kitabının baskısında ve sayfalarında kir ve leke bulunmamaktadır. Kitabın kapağı kalın karton kâğıda, iç sayfalarda yine kalın kâğıda basılmıştır. Baskı kalitesi, ciltleme ve iç sayfalarda kullanılan yazı ve resim kalitesi açısından kaliteli bir basım olduğu söylenebilir; tutkalla birleştirilen sayfalar sağlam yapıldığı için kolaylıkla birbirinden ve kapaktan ayrılmamaktadır. Azerbaycan 7. sınıf coğrafya ders kitabının baskısında ve sayfalarda kir ve leke bulunmamaktadır. Kapak kalın kuşe kâğıda basılmış iç sayfalar ise ince kâğıda basıldığ için 1şığa tutulduğunda arka sayfanın baskısı görülmektedir. Baskı kalitesi ve ciltleme açısından çok kaliteli bir basım olduğu söylenemez; tutkalla birleştirilen sayfalar kolaylıkla birbirinden ve kapaktan ayrılabilmektedir. Türkiye'de kullanılan ders kitabının Azerbaycan'da kullanılan ders kitabına göre daha iyi baskı kalitesine sahip olduğu görülmektedir.

\section{Öneriler}

Türkiye'de eğitim ile ilgili sorunların daha net bir şekilde görülmesi ve bu sorunların çözümü için faklı ülkelerin bakış açılarının öğrenilip uygulanması, karşılaştırmalı eğitim çalışmalarının artırılmasına bağlıdır. Bu nedenle karşılaştırmalı eğitim çalışmalarının sayısının arttırılması gerekmektedir. Türkiye'de ortaokul sosyal bilgiler öğretim programında coğrafya konularına daha fazla yer verilerek hem tarih, coğrafya ve vatandaşlık dengesi sağlanabilir hem de bu sayede sosyal bilgiler dersi içerisinde somut konular artırılmış olabilir. Türkiye'de ortaokul seviyesinde öğrencilerin coğrafya konusunda bilgi düzeyinin artırılması için seçmeli dersler içerisinde coğrafya dersine de yer verilebilir. Bu sayede ortaöğretime giderken öğrenciler temel coğrafi becerilere sahip olabilirler.

Türkiye'de ortaokul seviyesinde 40 dakika olarak uygulanan 1 ders saatinin, pedegojik standartlara uygun bir şekilde kısaltılması uygun olabilir. Azerbaycan coğrafya ders kitabının baskı kalitesi artırılıp konular içerisine görseli bol olan ölçme değerlendirme etkinlikleri eklenerek kitap daha ilgi çekici bir hale getirilebilir. Azerbaycan coğrafya ders kitabı sonunda kaynakça yer almamaktadır. Bilimsellik adına Azerbaycan coğrafya ders kitaplarının sonunda kaynakça bulunması doğru olacaktır. Azerbaycan 7. sınıf coğrafya müfredatındaki bilgi yoğunluğu azaltılarak yapılandırmacı yaklaşımla, öğrencinin bilgiye ulaşmasını sağlayacak bir 
program hazırlanabilir. Türkiye, Azerbaycan ve diğer Orta Asya Türk Cumhuriyetlerini de içine alacak şekilde, Türk dili temelinde ve Türk kültürünü konu alacak bir ders konularak aynı anda tüm Türk Cumhuriyetlerinde ortak bir değer oluşturulabilir. Araştırmacılar, karşılaştırmalı eğitim alanında genellikle gelişmiş ülkelerin eğitim sistemlerini incelemenin yanı sıra ortak bir kültüre sahip olduğumuz ülkelerin eğitim sistemlerini de inceleyerek ortak kültürümüzün yaşatılmasına destek olabilirler.

Karşılaştırmalı eğitim çalışmaları ülkeler arası benzerlik ve farklılıkların ortaya konulup eksikliklerin giderilmesi açısından büyük önem arz emektedir. Bu tür çalışmaların desteklenmesi ve araştırmacıların işlerinin kolaylaştııılması, çalışma sayısını artıracaktır. $\mathrm{Bu}$ konuda bakanlık birimlerinin bu çalışmalar sırasında gerekli bilgi ve materyallere ulaşma noktasında araştırmacılara destek sağlaması ve bürokratik engelleri ortadan kaldırması karşılaştırmalı eğitim çalışmalarının sayısını artırabilir.

\section{KAYNAKÇA}

Adıgüzel, O.C., \& Tatlı, S. (2012). Türkiye'deki lisansüstü karşılaştırmalı eğitim tezlerinin çok boyutlu bir incelemesi. Anadolu Üniversitesi Sosyal Bilimler Dergisi, 12(1), s. 143-150.

Atik, K. (2014). Tarih araştırmalarında yeni bir yöntem: karşılaştırmalı tarih. Uluslararası Avrasya Sosyal Bilimler Dergisi, 5(16), s. 272-291.

Azerbaycan Cumhuriyeti Anayasası (1995). http://www.anayasa.gen.tr/azerbaycan-aleskerli.htm adresinden edinilmiştir.

Azerbaycan Cumhuriyeti Eğitim Bakanlığı (2011). Azerbaycan cumhuriyeti genel eğitim okulları için coğrafya dersi müfredatı. http://www.muallim.edu.az/www.old/arxiv/2011/02/32.htm adresinden edinilmiştir

Azerbaycan Milli Kütüphanesi (2013). Azerbaycan cumhuriyeti genel eğitim mektepleri için coğrafya bilimi üzerine eğitim programı. http://anl.az/down/meqale/ayna/2011/yanvar/150595.htm adresinden edinilmiştir

Azerbaycan Cumhuriyeti Eğitim Bakanlığı (2009). Azerbaycan cumhuriyeti eğitim kanunu. http://edu.gov.az/az/page/451/302 adresinden edinilmiştir

Azerbaycan Devlet İstatistik Komitesi, (2016). Ĕgitim istatistikleri (2000-2016). http://www.stat.gov.az/source/education/source/education/adresinden edinilmiştir

Azerbaycan Devlet İstatistik Komitesi, (2018). Azerbaycan nüfus istatistikleri. https://www.stat.gov.az/source/demoqraphy/ap/ adresinden edinilmiştir.

Azerbaycan Cumhuriyeti Eğitim Bakanlığı, (2016). Azerbaycan tedris planına dair esaslar. http://edu.gov.az/upload/file/emre-elave/2016/614/614-sayli-emre-elave2.pdf adresinden edinilmiștir

Bilgili, A.S. (2012). Sosyal bilgilerin temelleri. Ankara: Pegem Akademi Yayınları.

Creswell, J.W. (2013). Nitel araştırma yöntemleri, beş yaklaşıma göre nitel araştırma ve araştırma deseni [e-kitap sürümü]. $\quad$ https://kupdf.net/download/john-w-creswell-nitel-aratrmayntemleripdf_5ad301dde2b6f5b9349ed763_pdf adresinden edinilmiştir.

Doğanay, H. Çavuş, A. (2013). Türkiye ekonomik coğrafyası. Ankara: Pegem Akademi Yayınları.

Erdoğan, İ. (2006). Çağdaş eğitim sistemleri. İstanbul: Sistem Yayıncılık.

Ergün, M. (1985). Karşılaştırmalı eğitim. İnönü Üniversitesi Eğitim Fakültesi Eğitim Bilimleri Bölümü, Malatya

Gedikoğlu, T. (2005). Avrupa birliği sürecinde Türk eğitim sistemi: sorunlar ve çözüm önerileri. Mersin Üniversitesi Ë̆itim Fakültesi Dergisi, 1(1), s. 66-80.

Güven, İ. Gürdal, A. (2011). Türkiye ile Kanada fen eğitiminin karşılaştırmalı olarak incelenmesi. Türk Fen Eğitimi Dergisi, 8(4), s. 89-110. 
Kab, İ. (2012). Türkiye'deki sosyal bilgiler ders kitaplarının Almanya'daki tarih, coğrafya ve vatandaşllk eğitimi ders kitaplarıyla karşılaş̧tırlması (Yüksek Lisans Tezi). Yükseköğretim Kurulu Ulusal Tez Merkezi’nden edinilmiştir. (Tez No. 320401)

Kızıltaş, E. Küçükoğlu, A. (2012). Almanya, Fransa, İngiltere, Rusya ve Türkiye okul öncesi öğretmen yetiştirme programlarının karşılaştırması. İlkögretim Online Dergisi, 11/3, s. 660-670.

Mammadov, J. (2008). Bağımsızllk sonrası Azerbaycan eğitim sistemindeki değişim ve gelişsmeler (Yüksek Lisans Tezi). Yükseköğretim Kurulu Ulusal Tez Merkezi’nden edinilmiştir. (Tez No. 261838)

Musayev, İ. (2010). Azerbaycan'da ailede din eğitimi (Yüksek Lisans Tezi). Yükseköğretim Kurulu Ulusal Tez Merkezi’nden edinilmiş̧ir. (Tez No. 262900)

Müseyibovun, M. (Ed.) (2009). 7. sınıf coğrafya ders kitabı. Bakü: Tahsil Yayıncılık

Oğan, S. (1992). Azerbaycan. İstanbul: Türk Dünyası Araştırmaları Vakfı Yayınları.

Özey, R. (2010). Türkiye ve komşu ülkeler coğrafyası. İstanbul: Aktif Yayınevi.

Öztürk, C. (2012). Sosyal bilgiler ögrretimi. Ankara: Pegem Akademi Yayınları

Sadıgov, İ. (2009). Azerbaycan ve Türkiye'de ortaöğretim coğrafya eğitim ve ögretiminin müfredatlar, metotlar ve kullanılan araç gereçler açısından değerlendirilmesi (Doktora Tezi). Yükseköğretim Kurulu Ulusal Tez Merkezi'nden edinilmiştir. (Tez No. 250885)

Safran, M. (2008). Sosyal bilgiler öğretimine bakış. B. Tay, A. Öcal (Ed.), Özel öğretim yöntemleriyle sosyal bilgiler ögretimi içinde (ss. 1-19). Ankara: Pegem Akademi Yayınları.

Seferov, R. Akkuş, A. (2005). Azerbaycan nüfusunun eğitim açısından analizi. Selçuk Üniversitesi Sosyal Bilimler Enstitüsü Dergisi, 13, s. 335-355.

Tatlı, S. (2010). Türkiye ve İngiltere ilköğretim 4. ve 5. siniflar müzik dersi ögrretim programlarının karşılaş̧tırlması (Yüksek Lisans Tezi). Yükseköğretim Kurulu Ulusal Tez Merkezi’nden edinilmiştir. (Tez No. 265729)

Tay, B. (2011). Sosyal bilgiler öğretiminin dünü, bugünü ve yarını. R. Turan, K. Ulusoy (Ed.), Sosyal bilgilerin temelleri içinde, (ss. 2-16). Ankara: Pegem Akademi Yayınları

TiKA. (1993). Azerbaycan ülke raporu. Ankara: TiKA Ajansı Yayınları

TÜIK, (2018). Adrese dayalı nüfus kaylt sistemi sonuçları. http://tuik.gov.tr/PreHaberBultenleri.do?id=21507 adresinden edinilmiştir.

Türkiye Cumhuriyeti Milli Eğitim Bakanlı̆̆ı, (1973). Milli eğitim temel kanunu. http://mevzuat.meb.gov.tr/html/temkanun_0/temelkanun_0.html adresinden edinilmiştir

Türkiye Cumhuriyeti Milli Eğitim Bakanlı̆̆ı, (2005). Sosyal bilgiler 5., 6. ve 7. sinıf öğretim programı. http://ttkb.meb.gov.tr/program2.aspx adresinden edinilmiştir.

Türkiye Cumhuriyeti Milli Eğitim Bakanlığı, (2016). Ilköğretim kurumları haftalık ders çizelgesi (2015-2016). http://ttkb.meb.gov.tr/www/haftalik-ders-cizelgeleri/kategori/7/1/ adresinden edinilmiştir.

Türkiye Cumhuriyeti Milli Eğitim Bakanlı̆̆ı, (2016). Milli eğitim istatistikleri örgün eğitim (2015-2016). http://sgb.meb.gov.tr/meb_iys_dosyalar/2016_03/30044345_meb_istatistikleri_orgun_egitim_2015_201 6.pdf adresinden edinilmiştir.

Türkiye Cumhuriyeti Resmi Gazetesi, (2017). Türkiye Cumhuriyeti anayasasında değişiklik yapılmasına dair kanun, Tarih: 11.02.2017 S. 29976

Türkiye Cumhuriyeti Resmî Gazetesi, (2017). Türkiye Cumhuriyeti anayasasında değişiklik yapılmasına dair kanun, Tarih; 21.01.2017 S. 6771

Türkiye İstatistik Kurumu, (2016). Türkiye örgün eğitim kurumları istatistikleri. http://www.tuik.gov.tr/PreTablo.do?alt_id=1018 adresinden edinilmiştir.

Türkiye Cumhuriyeti Diyanet İşsleri Başkanlığı, (2014). Türkiye'de dini hayat araştırması. http://www2.diyanet.gov.tr/StratejiGelistirme/Afisalanlari/dinihayat.pdf adresinden edinilmiştir. 
Türkoğlu, A. (2012). Karşılaş̧ırmalı eğitim nedir. Songül Aynal (Ed.) Karşılaştırmalı eğitim yansımaları içinde (ss. 1-22). Ankara: Pegem Akademi Yayınları.

Türkoğlu, A. (Editör), (2015). Karşılaştırmalı eğitim, dünya ülkelerinden örneklerle. Ankara: Anı Yayıncılık.

Uslu, S. (2014), Sosyal Bilgiler Öğretmen Adaylarının Özel Alan Yeterliklerine İlişkin Öz-Yeterlik İnançlarının İncelenmesi, (Doktora Tezi) Yükseköğretim Kurulu Ulusal Tez Merkezi’nden edinilmiştir. (Tez No. 354686)

Ültanır, G. (2000). Karşılaştırmalı eğitim bilimi kuram ve teknikler. Ankara: Eylül Kitap ve Yayınevi.

Yıldırım, A. Şimşek H. (2011). Sosyal bilimlerde nitel araştırma yöntemleri. Ankara: Seçkin Yayıncılık.

Zamanov, E. (2014). Sovyetler döneminde Azerbaycan'da eğitim hareketleri (Yüksek Lisans Tezi). Yükseköğretim Kurulu Ulusal Tez Merkezi’nden edinilmiştir. (Tez No. 364906) 


\title{
EXTENDED ABSTRACT
}

\author{
Comparison of Geographical Subjects within 7th Grade of Secondary Schools in \\ Turkey and Azerbaijan
}

\section{Introduction}

When comparing the educational systems of different countries, the only purpose is not to identify similar and different aspects. The main purpose is to take advantage of the information obtained from the educational systems of the countries being compared. To examine and compare the education systems of the two countries, which are very similar to the historical, cultural, geographical, economic and political structure are also important for these two countries to get to know each other.

The aim of this research is revealing the similarities and differences between geography lessons in Social Studies at the 7th grade level in the middle school in Turkey and Geography in Azarbaijan with comparing with curricula and textbooks based on the model.

\section{Method}

Qualitative research observation can be defined as the study in which qualitative data collection methods such as observotion, interview and document analysis are used, and a qualitative process intended for that perceptions and events are put in a realistic and holistic way in natural envirenment is followed.

Document analysis technique was applied in the research using qualitative research methods. The data was collected according to this technique. The data collection was started by examining the related researches that was related to the topic and then, the textbooks were provided in both countries. Country characteristics, education system, secondary school Geography curricula and textbooks were examined from the general to the specific.

\section{Result}

As a result of this study, it has been observed that the general characteristics of both countries have similar cultural characteristics when examined on the basis of Turkish language. It has been seen that educational systems have similarities with the general outlines of the general purpose of education systems. In Turkey, History, Geography and Citizenship subjects are in the same class but in Azerbaijan Geography and History are seperated from each other.

Also as a textbook, in the content of social studies textbooks used in Turkey, it has been seen that the topics like History, Geography and Citizenship Study under the name of Social Studies course take part, the print quality is well, lots of maps, images, figures, graphics and the visual related to the content of the unit and subjects as visual element are used in the coherent with paragraphs, the sufficient measurement and evaluation study evlautaing functions are taken part.

The geography textbook used in Azerbaijan has been detected that it is entirely formed of the subjects of geography; the visual quality is not very well, lots of maps, images, figures, graphics and the visual related to the content of the unit and subjects as visual element are used in the 
coherent with paragraphs, the sufficient measurement and evaluation study evlautaing functions are not taken part.

\section{Discussion}

Radical changes in the educational history of both countries played an important role in determining the educational policies. It has been determined that this situation, which has similar characteristics as general language of education, general laws of education and general structure of education system, will provide significant easiness in common culture studies. İn terms of department trainig, in Azerbaijan more place and time are given to geograhpy department in the same educational level but in Turkey the geography department is given part in Social Studies course as a function.

It has been determined that education systems of both countries have similar characteristic on the basis of Turkish language. Giving more place to the Geography in Social Studies will embody the lesson in Turkey.It will be better to increase the print quaility and visual quality of coursebook which is taught in Azarbaijan as a textbook.

In Turkey, that issues related education are seen more clearly and, that different countries' perspectives are learned and practised for the solution of these issues depend on increasing comparative education studies. In this reason, the number of comparative educational studies should be increased.

In the name of development common culture between Turkey and Azerbaijan, as the studies such as Erasmus and similar projects implemented by European countries are done, students and teachers can be exchanged mutually and cultural activities can be organized through onsite examinations 